\title{
Oxidative injury induced by hypochlorous acid to Ca-ATPase from sarcoplasmic reticulum of skeletal muscle and protective effect of trolox
}

\author{
Miriam Strosova ${ }^{1,3}$, Jana Karlovska ${ }^{2}$, Corinne M. Spickett ${ }^{3}$, Tilman Grune ${ }^{4}$, Zuzana \\ Orszagova ${ }^{5}$ and Lubica Horakova ${ }^{1}$ \\ ${ }^{1}$ Institute of Experimental Pharmacology, Slovak Academy of Sciences, Bratislava, Slovakia \\ ${ }^{2}$ Department of Physical Chemistry of Drugs, Faculty of Pharmacy, Comenius University, Bratislava, Slovakia \\ ${ }^{3}$ Department of Bioscience, University of Strathclyde, Glasgow, Scotland, UK \\ ${ }^{4}$ Institute of Biological Chemistry and Nutrition, University of Hohenheim, Stuttgart Germany \\ ${ }^{5}$ Department of Medical Chemistry and Biochemistry, Faculty of Medicine, Comenius University, Bratislava, Slovakia
}

\begin{abstract}
Hypochlorous acid ( $\mathrm{HOCl})$ concentration-dependently decreased ATPase activity and SH groups of pure Ca-ATPase from sarcoplasmic reticulum (SERCA) of rabbit skeletal muscle with $\mathrm{IC}_{50}$ of $150 \mu \mathrm{mol} / \mathrm{l}$ and $6.6 \mu \mathrm{mol} / \mathrm{l}$, respectively. This indicates that $\mathrm{SH}$ goups were not critical for impairment of Ca-ATPase activity. Pure Ca-ATPase activity was analysed individually with respect to both substrates, $\mathrm{Ca}^{2+}$ and ATP. Concerning dependence of ATPase activity on $\mathrm{HOCl}(150 \mu \mathrm{mol} / \mathrm{l})$ as a function of free $\mathrm{Ca}^{2+}$ and ATP, $V_{\text {max }}$ of both dependences decreased significantly, while the affinities to individual substrates were not influenced, with the exception of the regulatory binding site of ATP.

On increasing $\mathrm{HOCl}$ concentration, fluorescence of fluorescein-5-isothiocyanate (FITC) decreased, indicating binding of $\mathrm{HOCl}$ to nucleotide binding site of SERCA. A new fragment appeared at $75 \mathrm{kDa}$ after $\mathrm{HOCl}$ oxidation of SR, indicating fragmentation of SERCA. Fragmentation may be associated with protein carbonyl formation. The density of protein carbonyl bands at 75 and $110 \mathrm{kDa}$ increased concentration- and time-dependently.

Trolox $(250 \mu \mathrm{mol} / \mathrm{l})$ recovered the Ca-ATPase activity decrease induced by $\mathrm{HOCl}$, probably by changing conformational properties of the Ca-ATPase protein. Trolox inhibited FITC binding to SERCA.
\end{abstract}

Key words: Ca-ATPase - HOCl oxidative stress - Trolox

\begin{abstract}
Abbreviations: BSA, bovine serum albumin; $\mathrm{Ca}^{2+}$ free, free calcium ions; DNPH, dinitrophenylhydrazine; FITC, fluorescein-5-isothiocyanate; $h$, Hill coefficient - an indicator of steepness of the curve; I, intensity; $\mathrm{IC}_{50}$, half maximal inhibitory concentration; PAPC, palmitoyl-arachidonoyl phosphatidylcholine; PCs, phosphatidylcholines; PEs, phosphatidylethanolamines; PLPC, palmitoyllinoleoyl phosphatidylcholine; POPC, palmitoyl-oleoyl phosphatidylcholine; SERCA, skeletal muscle sarcoplasmic/endoplasmic reticulum Ca-ATPase; ER/SR, endoplasmic/sarcoplasmic reticulum.
\end{abstract}

\section{Introduction}

Stimulated polymorphonuclear neutrophilic granulocytes cells, present under inflammatory conditions, produce highly reactive species such as superoxide anion and hydrogen

Correspondence to: Lubica Horakova, Institute of Experimental Pharmacology, Slovak Academy of Sciences, Dúbravská cesta 9, 84104 Bratislava, Slovakia

E-mail: Lubica.Horakova@savba.sk peroxide $\left(\mathrm{H}_{2} \mathrm{O}_{2}\right)$, and also release the enzyme myeloperoxidase (Jesaitis and Dratz 1992; Schaur et al. 1998). The highly reactive biological oxidant hypochlorous acid $(\mathrm{HOCl})$ is generated via the myeloperoxidase-catalysed oxidation of the physiological concentrations of chloride $\left(\mathrm{Cl}^{-}\right)$by $\mathrm{H}_{2} \mathrm{O}_{2}$ (Zavodnik et al. 2001; Winterbourn 2002). HOCl plays an important role in both microbial killing and inflammatory tissue injury by neutrophils (Soszyński et al. 2002) and has been implicated also in the diseases or pathological states like ischemia/reperfusion, atherosclerosis, skeletal muscle 
dysfunction, rheumatoid arthritis and in infammatory conditions (Pullar et al. 1999; Soszyński et al. 2002), and is believed to participate in the development of atherosclerotic lesions (Zabe et al. 1999).

The toxicity of $\mathrm{HOCl}$ is based on its ability to react with biological target molecules including lipids, proteins and DNA, forming long-lived chloramines on reaction with amine group (Vissers and Winterbourn 1995; Carr and Winterbourn 1997; Hawkins and Davies 1998; Winterbourn 2002; Robaszkiewicz et al. 2008a,b). Lysine residues appear to be a major site of reaction of $\mathrm{HOCl}$ with many proteins (Zavodnik et al. 2001). The result of this process is chloramine species, which subsequently decompose to give nitrogen-centred protein radicals. These radicals are key species in $\mathrm{HOCl}$-induced protein backbone fragmentation and dimerisation (Hawkins and Davies 1998).

Low sublethal doses of $\mathrm{HOCl}$ react with cellular thiols (glutathione and protein thiols) and could modulate specific cell processes, e.g. initiate apoptosis (Pullar et al. 1999; Vissers et al. 1999). HOCl induces caspase activity and can modify cellular responses that are dependent on various signal transductuin pathways. Higher concentrations of $\mathrm{HOCl}$ cause rapid necrosis (Vissers et al. 1999). Oxidation of SH groups, tryptophan (Trp) residues, chloramine formation, changes of membrane fluidity, etc. are events included in injury of ion transport ATPases in erythrocytes induced by $\mathrm{HOCl}$, preceding cell lysis (Zavodnik et al. 2001).

Previously we found that trolox, a water soluble derivative of a tocopherol, was able to prevent skeletal muscle sarcoplasmic reticulum (SR) Ca-ATPase activity decrease after oxidation of $\mathrm{SR}$ vesicles by $\mathrm{HOCl}$ (Strosova et al. 2005a). In this work we analysed the protective effect of trolox on pure Ca-ATPase from the same source, with the aim to attempt to explain the mechanisms of this prevention. Possible structural changes of skeletal muscle sarcoplasmic/endoplasmic reticulum Ca-ATPase (SERCA) involved in $\mathrm{HOCl}$-induced injury, as well as in the trolox protective effect, were investigated in SR vesicles.

\section{Materials and Methods}

\section{Isolation of SR and pure Ca-ATPase}

SR vesicles and pure Ca-ATPase (EC 3.6.1.38) were isolated from skeletal muscles of New Zealand rabbits according to Warren et al. (1974a,b), as modified by Karlovska et al. (2005).

\section{Oxidation of SR vesicles}

For determination of enzyme activity, SR vesicles or pure Ca-ATPase (0.1 mg protein $/ \mathrm{ml}$ ) from rabbit skeletal muscles were oxidised by $\mathrm{HOCl}(50-200 \mu \mathrm{mol} / \mathrm{l})$ for $3 \mathrm{~min}$ at $25^{\circ} \mathrm{C}$,
$\mathrm{pH}$ 7.2. The oxidation was stopped by the addition of cysteine ( $1 \mathrm{mmol} / \mathrm{l})$. Description of SR or pure SERCA oxidation for determination individual markers of oxidative injury is specified in the figure legends.

\section{Ca-ATPase activity}

Enzyme activity of Ca-ATPase from SR (SERCA) of rabbit skeletal muscles was measured by NADH-coupled enzyme assay outlined by Warren et al. (1974a,b) and modified by Karlovska et al. (2006). The SR vesicles (final concentration $12.5 \mu \mathrm{g}$ protein/cuvette) were added to the assay mixture $(40 \mathrm{mmol} / \mathrm{l}$ Hepes (pH 7.2), $0.1 \mathrm{~mol} / \mathrm{l} \mathrm{KCl,} 5.1 \mathrm{mmol} / \mathrm{MgSO}_{4}, 2.1 \mathrm{mmol} / \mathrm{l}$ ATP, $0.52 \mathrm{mmol} / \mathrm{l}$ phosphoenolpyruvate, $1 \mathrm{mmol} / \mathrm{l} \mathrm{EGTA,} 0.15$ $\mathrm{mmol} / \mathrm{l} \mathrm{NADH}, 7.5 \mathrm{IU}$ of pyruvate kinase, $18 \mathrm{IU}$ of lactate dehydrogenase), and incubated at $37^{\circ} \mathrm{C}$ for $15 \mathrm{~min}$. The reaction was started by the addition of $\mathrm{CaCl}_{2}$ (final concentration $1 \mathrm{mmol} / \mathrm{l})$. The reaction rate was determined by measuring the decrease in NADH absorbance at $340 \mathrm{~nm}$, at $37^{\circ} \mathrm{C}$.

ATPase activity was also studied as a function of free $\mathrm{Ca}^{2+}$ concentrations and ATP. Concentrations of free $\mathrm{Ca}^{2+}$ were calculated by the computer program Maxchelator (Patton 2004) using the binding affinities described by Gould et al. (1986). The dependence of ATPase activity on free $\mathrm{Ca}^{2+}$ concentration was fitted to the Hill equation:

$$
A=\frac{V_{\max }\left[C a_{\text {free }}^{2+}\right]^{h}}{K^{h}+\left[C a_{\text {free }}^{2+}\right]^{h}}
$$

where $V_{\text {max }}$ is the activity of Ca-ATPase at saturated concentration of the substrate, $K$ is the concentration of $\mathrm{Ca}^{2+}$ free corresponding to one-half of $V_{\text {max }}$, and $h$ is the Hill coefficient, an indicator of steepness of the curve, describes the cooperativity of binding sites of the enzyme studied.

The dependence of ATPase activity on ATP concentration was fitted to the bi-Michaelis-Menten equation according to Kosk-Kosicka (1983) and Michelangeli et al. (1991):

$$
[E P]=\frac{V_{\max }^{\prime} \cdot[M g \cdot A T P]}{K_{m}^{\prime}+[M g \cdot A T P]}+\frac{V_{\max }^{\prime \prime} \cdot[M g \cdot A T P]}{K_{m}^{\prime \prime}+[M g \cdot A T P]}
$$

where $V_{\text {max }}^{i}$ is the activity at saturated concentrations of the substrate and $K_{m}^{i}$ is the Michaelis constant. The indices I = I and II mean high- and low-affinity binding sites, respectively.

\section{SH group determination}

The content of SH groups in pure Ca-ATPase was determined spectrophotometrically by measuring of absorbance at $412 \mathrm{~nm}$ after reaction with DTNB (5,5' -dithiobis(2-nitrobenzoic acid) (Favero et al. 1998). Pure Ca-ATPase (200 $\mu \mathrm{g}$ protein/ml) was incubated for $10 \mathrm{~min}$ at $25^{\circ} \mathrm{C}$ in $50 \mathrm{mmol} / \mathrm{l}$ Tris with $\mathrm{HOCl}$. 


\section{SDS-PAGE}

SR proteins $(1 \mathrm{mg} / \mathrm{ml})$ were separated according to Laemmli (1970) by denaturising sodium dodecyl sulphate-polyacrylamide gel electrophoresis (SDS-PAGE) using a miniPROTEAN II electrophoresis cell (Bio-Rad, Munich, Germany). Aliquots of the samples in Laemmli-buffer ( $\mathrm{pH} 6.8$ ) containing $25 \mathrm{mmol} / \mathrm{l}$ Tris, $1 \%$ SDS, $0.192 \mathrm{~mol} / \mathrm{l}$ glycine, $1 \%$ bromphenole blue, and 5\% mercaptoethanol added freshly to the buffer each time, were incubated for $10 \mathrm{~min}$ at $95^{\circ} \mathrm{C}$ and then loaded onto a SDS-PAGE (7.5\% separating- and $4 \%$ stacking-gel). The separation was performed for $0.5 \mathrm{~h}$ at $50 \mathrm{~V}$ and afterwards for approximately $2 \mathrm{~h}$ at $150 \mathrm{~V}$ until the first marker reached the end of the gel. Visualisation was performed by Coomassie Brilliant Blue staining.

\section{ELISA}

A sensitive enzyme linked immunosorbent assay (ELISA) as described by Buss et al. (1997) was used for the quantitative determination of protein carbonyls in SR vesicles. Protein samples were derivatised with dinitrophenylhydrazine (DNPH) and adsorbed in multiwell-plates (Nunc Immunosorp Plates, Roskilde, Denmark). A biotin-conjugated anti-dinitrophenyl-rabbit-IgG-antiserum (Sigma, USA) was used as primary antibody and a monoclonal anti-rabbit-IgG-antibody peroxidase conjugate (Sigma, USA) as secondary antibody. The development was performed with o-phenylendiamine. Absorbance was determined at $492 \mathrm{~nm}$. The method was calibrated using oxidised bovine serum albumin (BSA). Oxidised and reduced BSA were prepared according to the method of Buss et al. (1997).

\section{Western-blot for protein carbonyl determination}

The protein-bound carbonyls in the SR vesicles were derivatised with DNPH, separated by SDS-PAGE, and transferred to nitrocellulose membrane (Hybond-P; Amersham Biosciences, Munich, Germany) by semidry immunoblotting. The detection was performed by enzymatic chemiluminescent system (Amersham Biosciences, Munich, Germany) after incubation with a primary antibody (biotinylated anti-DNP-rabbit-IgG-antibody) against DNP-adducts and a peroxidase-labelled secondary anti-rabbit-IgG antibody against the first one. Densitometric quantification of the protein-bound carbonyls was done by FluorChem 8900 software, version 3.2.3. (Alpha Innotech Corporation).

\section{Trp fluorescence}

The fluorescence intensity of Trp residues in water is low with the emission maximum at $358 \mathrm{~nm}$, and in dioxane (nonpolar environment) it is high, with the emission maximum at
$336 \mathrm{~nm}$ (Restall et al. 1986). The intensity ratio $\mathrm{I}_{358 \mathrm{~nm}} / \mathrm{I}_{336 \mathrm{~nm}}$ corresponds to fluorescence of Trp residues in polar (cytosol) and nonpolar (membrane) environment and can be a marker of SERCA conformational changes. Trp fluorescence in membrane proteins of SR was measured on a Perkin Elmer LS45 spectrofluorometer (Waltham, Massachusetts, USA) at $25^{\circ} \mathrm{C}$. Trp emission spectra were collected by exciting at 290 $\mathrm{nm}$ and the emission spectra were recorded in the range of 300-450 nm (Carney et al. 2007).

\section{Labelling of Ca-ATPase by FITC}

ATPase from SR was labelled with fluorescein-5-isothiocyanate (FITC) according to the method described by Froud and Lee (1986). FITC 'Isomer I' was obtained from Invitrogen $^{\mathrm{TM}}$ (Carlsbad, USA). When FITC: ATPase labelling ratios are below $1: 1$, at $\mathrm{pH} 8$, reaction of binding FITC to ATPase is complete, so that separation of bound and free FITC became unnecessary (Froud and Lee 1986).

We used FITC : ATPase labelling ratio of approx. $0.5: 1$. $\mathrm{SR}(0.6 \mathrm{mg})$ in $1 \mathrm{~mol} / \mathrm{l} \mathrm{KCl}, 0.25 \mathrm{~mol} / \mathrm{l}$ sucrose and $50 \mathrm{mmol} / \mathrm{l}$ Hepes (pH 8), in the volume $35 \mu$ l was incubated with 2.5 nmol of FITC. Stock solution of FITC $(6 \mathrm{mmol} / \mathrm{l})$ was prepared in dry dimethylformamide. The reaction mixture was left to stand at room temperature in dark for $1 \mathrm{~h}$ and then diluted with $250 \mu \mathrm{l}$ of $0.2 \mathrm{~mol} / \mathrm{l}$ sucrose and $50 \mathrm{mmol} / \mathrm{l}$ Tris- $\mathrm{HCl}$ ( $\mathrm{pH}$ 7). Labelled samples were stabilised $30 \mathrm{~min}$ at room temperature and stored on ice until use.

Fluorescence spectra were measured on a Perkin Elmer LS45 spectrofluorometer (Waltham, Massachusetts, USA) at $25^{\circ} \mathrm{C}$. Labelled protein $(15 \mu \mathrm{g})$ was added to $1 \mathrm{ml}$ of $5 \mathrm{mmol} / \mathrm{l}$ $\mathrm{MgSO}_{4}, 100 \mathrm{mmol} / \mathrm{l} \mathrm{KCl}$ and $50 \mathrm{mmol} / \mathrm{l}$ Tris- $\mathrm{HCl}$ buffer (pH 7) at $25^{\circ} \mathrm{C}$. EGTA and $\mathrm{CaCl}_{2}$ were added from stock solutions to give total concentrations of $25 \mu \mathrm{mol} / 1$ and 0.8 $\mathrm{mmol} / \mathrm{l}$, respectively. Fluorescence spectra were collected by exciting at $485 \mathrm{~nm}$ and the emission spectra were recorded in the range of $500-600 \mathrm{~nm}$.

\section{ES-MS and LC-MS}

Electrospray mass spectrometry (ES-MS) was performed in positive-ion mode on a LCQ Duo circular ion trap mass spectrometer (Thermo-Finnigan, Hemel Hempstead, UK). For direct infusion of samples, the solvent system was $9: 1$ methanol/water $(\mathrm{v} / \mathrm{v})$, with a flow rate of $5 \mu \mathrm{l} / \mathrm{min}$. The capillary temperature was set to $200^{\circ} \mathrm{C}$, with a nebulising gas flow of $20 \mathrm{l} / \mathrm{h}$ and a drying gas flow of $400 \mathrm{l} / \mathrm{h}$. Data were collected between 400 and $1000 \mathrm{~m} / \mathrm{z}$. Rat SR vesicles were reconstituted in 9:1 methanol/water (v/v) (usually $1 \mu \mathrm{l}$ in $100 \mu \mathrm{l})$ and diluted 10 -fold in this solvent.

Reverse phase liquid chromatography-MS (LC-MS) was carried out essentially as described previously 
A

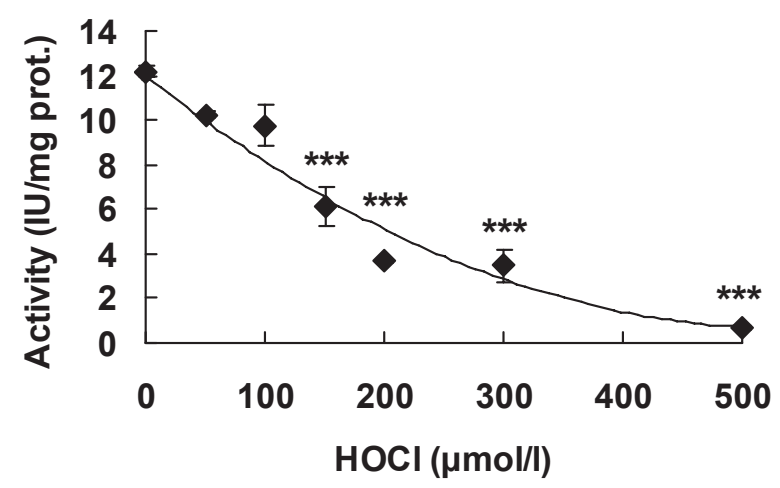

B

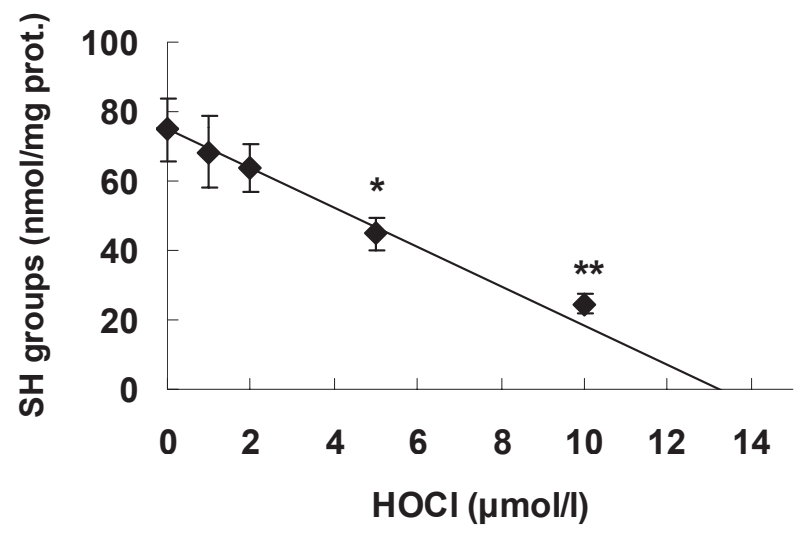

Figure 1. HOCl concentration-dependence of purified Ca-ATPase activity (A) and SH group content in purified enzyme (B). Purified Ca-ATPase (0.1 mg prot./ml (A), $0.2 \mathrm{mg}$ prot./ml (B)) was exposed to various concentrations of $\mathrm{HOCl}$ for $3 \mathrm{~min}(\mathrm{~A})$ or for $10 \mathrm{~min}(\mathrm{~B})$ at $25^{\circ} \mathrm{C}$ and $\mathrm{pH}$ 7.2. Values are means \pm SEM of 3 independent measurements with at least 3 parallels. ${ }^{\star} p<0.05,{ }^{\star *} p<0.01,{ }^{* * *} p<0.001$ are significant differences between control and by $\mathrm{HOCl}$ oxidised samples.

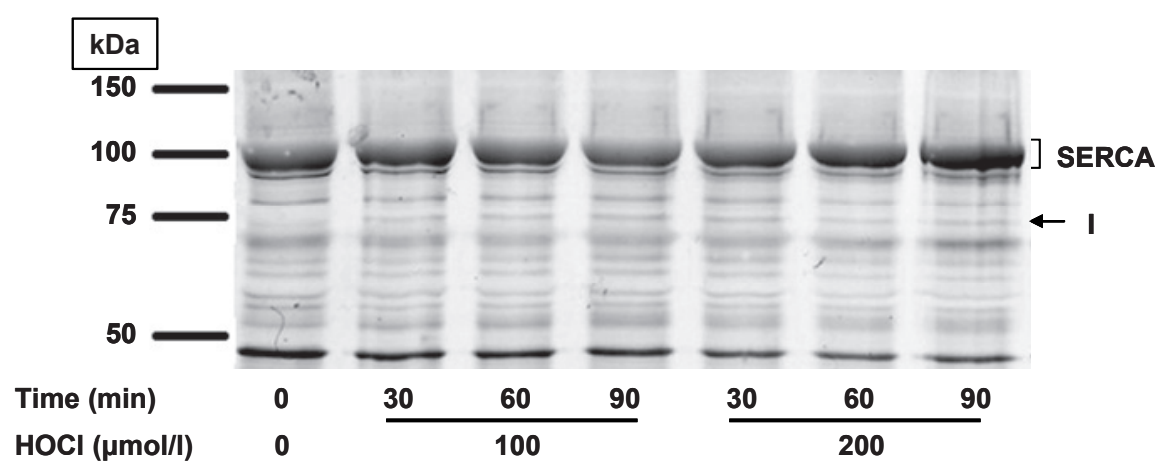

Figure 2. SDS-PAGE of SERCA oxidised by HOCl. SR ( $1 \mathrm{mg}$ prot./ml) was exposed to $\mathrm{HOCl}(100$ and $200 \mu \mathrm{mol} / \mathrm{l})$ at $\mathrm{pH} 7.2$ and $37^{\circ} \mathrm{C}$, for 30, 60 and $90 \mathrm{~min}$. Proteins were separated on SDS-PAGE and visualised by Coomassie Brilliant Blue. The arrow marked band around $75 \mathrm{kDa}$ represents fragment I. The gel shows 1 representative of 3 independent experiments.

(Spickett et al. 2001), but using a Thermo-Finnigan Surveyor system and a Luna C8 column (5 $\mathrm{m}$ RP-Sct, $1 \mathrm{~mm}$ inner diameter $\times 150 \mathrm{~mm}$; Phenomenex, UK). This column was operated at a flow rate of $100 \mu \mathrm{l} / \mathrm{min}$ with an isocratic solvent system of $71: 4: 8$ (by vol.) methanol/ hexane $/ 0.1 \mathrm{~mol} / \mathrm{l}$ aq. ammonium acetate. Rat SR vesicles were reconstituted in $9: 1$ methanol/water as above and diluted 5 -fold in running solvent; $20 \mu \mathrm{l}$ of sample were injected per run.

Reconstructed ion chromatograms showing individual molecular species were generated using Excalibur software (Thermo-Finnigan), and were mean-smoothed. In all the spectra and chromatograms shown the percentage scale on the vertical axes corresponds to intensity related to that of the largest peak in the region analysed, unless otherwise stated.

\section{Statistical data analysis}

For statistical analysis we used unpaired one-way ANOVA test with Dunnett post hoc comparsion (nonparametric test) for mutual comparsion of treated samples with control.

All procedures involving animals were performed in compliance with the Principles of Laboratory Animal Care issued by the Ethical Committee of the Institute of Experimental Pharmacology, Slovak Academy of Sciences, and by the State Veterinary and Food Administration of the Slovak Republic. 
A

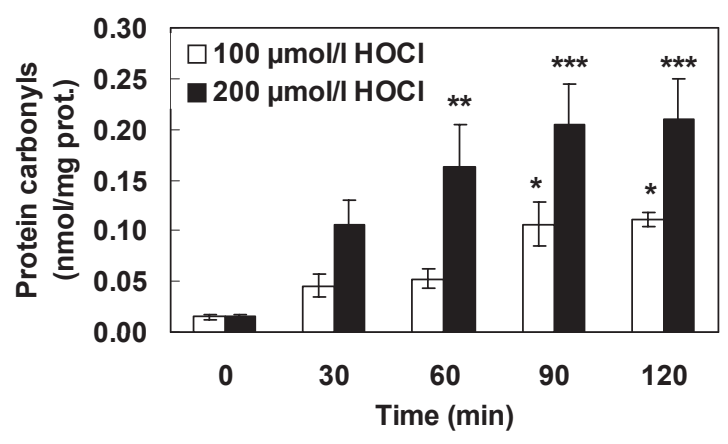

B

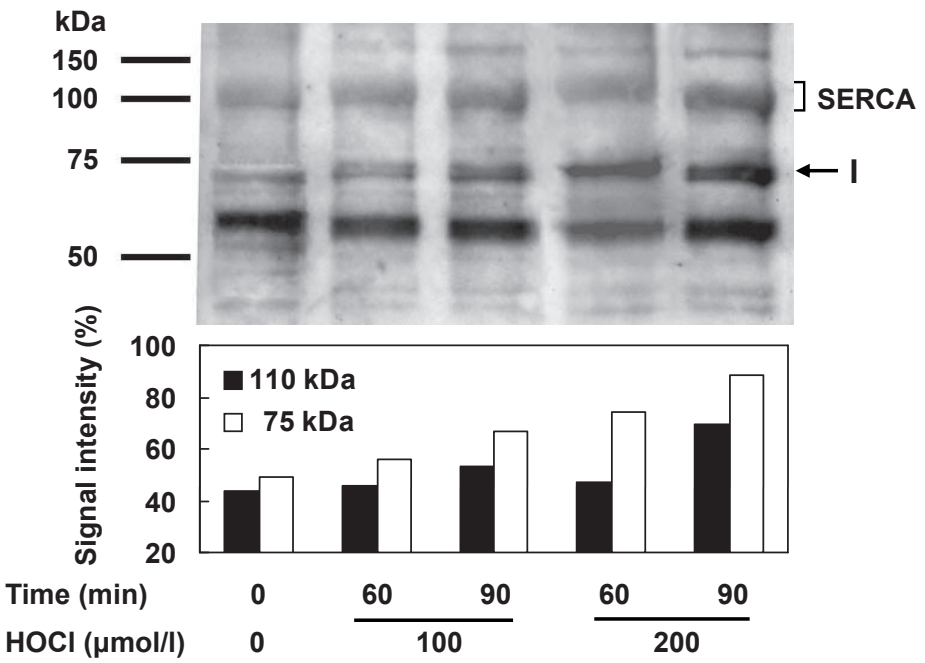

Figure 3. Protein carbonyl formation in SERCA in time course of incubation by HOCl. SR ( $1 \mathrm{mg}$ prot./ml) was exposed to $\mathrm{HOCl}$ (100 and $200 \mu \mathrm{mol} / \mathrm{l}$ ) at $\mathrm{pH} 7.2$ and $37^{\circ} \mathrm{C}$, for 30, 60, 90 and $120 \mathrm{~min}$. Protein carbonyls were either determined by ELISA (A) or by the immunoblot detection of protein bound carbonyls after derivatisation with DNPH (B). The blot shows 1 representative of 3 independent experiments. The signal intensity of protein carbonyls of SERCA and fragment I quantified by FluorChem 8900 software (version 3.2.3. Alpha Innotech Corporation) is shown in panel B. Values of ELISA are mean \pm SEM of 3 independent measurements with at least 3 replicates. ${ }^{*} p<0.05,{ }^{* *} p<0.01,{ }^{* * *} p<0.001$ are significant differences between control and $\mathrm{HOCl}-$ oxidised samples.

\section{Results}

Effects of $\mathrm{HOCl}$ and possible protective effects of trolox on pure Ca-ATPase activity from rabbit skeletal muscles were studied. We found that $\mathrm{HOCl}$ decreased purified Ca-ATPase activity concentration-dependently and that $\mathrm{IC}_{50}$ of this decrease was $150 \mu \mathrm{mol} / \mathrm{l}$ (Fig. 1A). Analogously, SH groups of this enzyme decreased following $\mathrm{HOCl}$-treatment in a concentration-dependent manner (Fig. 1B), with $\mathrm{IC}_{50}$ of $6.6 \mu \mathrm{mol} / \mathrm{l}$. In SR vesicles, $70-90 \%$ of protein is Ca-ATPase (Warren et al. 1974a; Castilho et al. 1996). The effect of HOCl on SR protein was tested by PAGE following treatment with two concentrations ( 100 and $200 \mu \mathrm{mol} / \mathrm{l})$ of $\mathrm{HOCl}$ in time courses of 30, 60, $90 \mathrm{~min}$. Incubation of SERCA with $\mathrm{HOCl}$ induced generation of a new band at approximately $75 \mathrm{kDa}$ (Fig. 2), indicating fragmentation of the protein.

Protein carbonyls in SR were analysed by ELISA and by Western immunoblotting (Fig. 3). Analysis by ELISA was performed at $\mathrm{HOCl}$ concentrations of 100 and $200 \mu \mathrm{mol} / \mathrm{l}$ in the time course of 0-120 min. A linear increase in carbonyls (0-90 min) was observed over time when 100 or $200 \mu \mathrm{mol} / 1$ $\mathrm{HOCl}$ was incubated with SR, reaching a plateau at $120 \mathrm{~min}$. A higher content of protein carbonyls was identified when SR was incubated with $200 \mu \mathrm{mol} / \mathrm{l} \mathrm{HOCl}$. Immunoblotting was used to analyse protein carbonyls in SR after incubation with 100 and $200 \mu \mathrm{mol} / \mathrm{l} \mathrm{HOCl}$ at two time points, 60 and 90 $\mathrm{min}$. The density of bands at 110 and $75 \mathrm{kDa}$ increased with increasing $\mathrm{HOCl}$ concentration and was time-dependent.

Structural changes of Ca-ATPase may be responsible for Ca-ATPase activity decrease, according to fluorescence studies like FITC and Trp fluorescence. The fluorescent probe FITC was used to assess structural alteration of the ATP (nucleotide) binding site of the SERCA protein, because FITC binding is localised at a specific lysine residue $\left(\mathrm{Lys}^{515}\right)$ comprised in this binding site. $\mathrm{HOCl}$ concentration-dependently decreased fluorescence of FITC (Fig. 4A). Similarly, trolox significantly decreased FITC fluorescence intensity (Fig. 4B), inhibiting the binding of FITC to the ATPase protein in nucleotide binding site. The ratio of fluorescence intensities $\mathrm{I}_{358 \mathrm{~nm}} / \mathrm{I}_{336 \mathrm{~nm}}$ of $\operatorname{Trp}$ residues in polar (cytosol) and nonpolar (membrane) environment can be a marker of SERCA conformational changes. $\mathrm{HOCl}$ did not alter the $\mathrm{I}_{358 \mathrm{~nm}} / \mathrm{I}_{336 \mathrm{~nm}}$ ratio (Fig. $4 \mathrm{C}$ ).

Lipid content and possible lipid oxidation in SR was analysed by ES-MS and by high performance liquid chromatography with detection by ES-MS (LC-MS). The native SR membranes from rabbit muscles consisted mainly of phosphatidylcholines (PCs) and phosphatidylethanolamines (PEs) containing saturated and unsaturated fatty acyl chains (Table 1). The intensity of the signals corresponding to PCs was nearly 10-times higher than that of the PEs. While palmitoyl-containing PCs dominated 
A
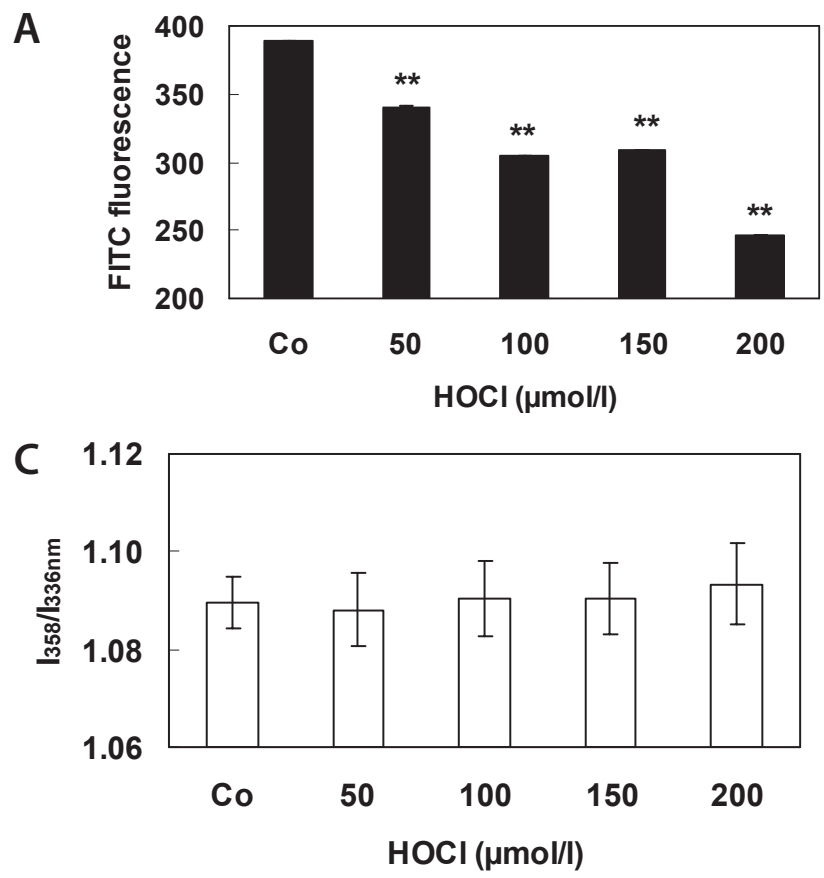

B

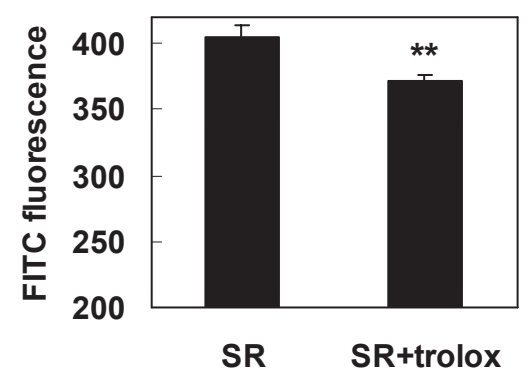

Figure 4. Maximum FITC fluorescence (A and $\mathrm{B}$ ) and ratio of Trp fluorescence intensity $\mathrm{I}_{358 \mathrm{~nm}} / \mathrm{I}_{336 \mathrm{~nm}}(\mathrm{C})$ in SR vesicles. SR $(25 \mathrm{mg}$ prot./ $/ \mathrm{ml})$ was exposed to various concentrations of $\mathrm{HOCl}$ for $3 \mathrm{~min}$ at $25^{\circ} \mathrm{C}$ and $\mathrm{pH} 7.2$ (A and C). Panel B shows data from SR $(25 \mathrm{mg}$ prot. $/ \mathrm{ml})$ treated by $250 \mu \mathrm{mol} / \mathrm{l}$ trolox for $2 \mathrm{~min}$ at $37^{\circ} \mathrm{C}$ and $\mathrm{pH} 7.2$. Values are means \pm SD of 10 measurements. ${ }^{* *} p<0.01$ are significant differences between control and $\mathrm{HOCl}$-oxidised samples.

Table 1. Phosphatidylcholines (PCs) and phosphatidylethanolamines (PEs) in native SR membranes. Spectra were recorded on a Thermo-Finnigan Surveyor system

PCs

\begin{tabular}{|c|c|c|c|c|}
\hline \multirow{2}{*}{ Name } & \multicolumn{2}{|c|}{$\mathrm{m} / \mathrm{z}$} & \multirow{2}{*}{ FAs } & \multirow{2}{*}{ Signal } \\
\hline & $\mathrm{H}^{+}$ & $\mathrm{Na}^{+}$ & & \\
\hline $\mathrm{DP}_{1} \mathrm{PC}$ (palmitoyl-palmitoleoyl) & 732 & 754 & $16: 0,16: 1$ & -- \\
\hline DPPC (dipalmitoyl) & 734 & 756 & $16: 0,16: 0$ & -- \\
\hline PLPC (palmitoyl-linoleoyl) & 758 & 780 & $16: 0,18: 2$ & +++ \\
\hline POPC (palmitoyl-oleoyl) & 760 & 782 & $16: 0,18: 1$ & ++ \\
\hline PAPC (palmitoyl-arachidonoyl) & 782 & 804 & $16: 0,20: 4$ & +++ \\
\hline $\mathrm{SL}_{3} \mathrm{PC}$ (stearoyl-linolenoyl) & 784 & 806 & $18: 0,18: 3$ & - \\
\hline SLPC (stearoyl-linoleoyl) & 786 & 808 & $18: 0,18: 2$ & -- \\
\hline $\mathrm{PD}_{6} \mathrm{PC}$ (palmitoyl-decosahexaenoyl) & 806 & 828 & $16: 0,22: 6$ & - \\
\hline $\mathrm{PD}_{5} \mathrm{PC}$ (palmitoyl-decosaheptaenoyl) & 808 & 830 & $16: 0,22: 5$ & - \\
\hline SAPC (stearoyl-arachidonoyl) & 810 & 832 & $18: 0,20: 4$ & - \\
\hline
\end{tabular}

PEs

\begin{tabular}{|l|c|c|c|c|}
\hline \multirow{2}{*}{ Name } & \multicolumn{2}{|c|}{$\mathrm{m} / \mathrm{z}$} & \multirow{2}{*}{ FAs } & \multirow{2}{*}{ Signal } \\
\cline { 2 - 3 } & $\mathrm{H}^{+}$ & $\mathrm{Na}^{+}$ & & -- \\
\hline PLPE (palmitoyl-linoleoyl) & 716 & 738 & $16: 0,18: 2$ & -- \\
\hline PAPE (palmitoyl-arachidonoyl) & 740 & 762 & $16: 0,20: 4$ & -- \\
\hline $\mathrm{SL}_{3} \mathrm{PE}$ (stearoyl-linolenoyl) & 742 & 764 & $18: 0,18: 3$ & -- \\
\hline SLPE (stearoyl-linoleoyl) & 744 & 766 & $18: 0,18: 2$ & ++ \\
\hline PD $_{6}$ PC (palmitoyl-decosahexaeoyl) & 764 & 786 & $16: 0,22: 6$ & -- \\
\hline SAPE (stearoyl-arachidonoyl) & 768 & 790 & $18: 0,20: 4$ & ++ \\
\hline SD $_{6}$ PC (stearoyl-decosahexaeoyl) & 792 & 814 & $18: 0,22: 6$ & + \\
\hline SD $_{5}$ PC (stearoyl-decosaheptaenoyl) & 794 & 816 & $18: 0,22: 5$ & -- \\
\hline
\end{tabular}

FAs, fatty acyl chains. Intensity of phospholipids signals are: +++ very strong, ++ strong, + medium, - weak, - - very weak. 


\section{A SR Oxidized by $\mathrm{HOCl}$}

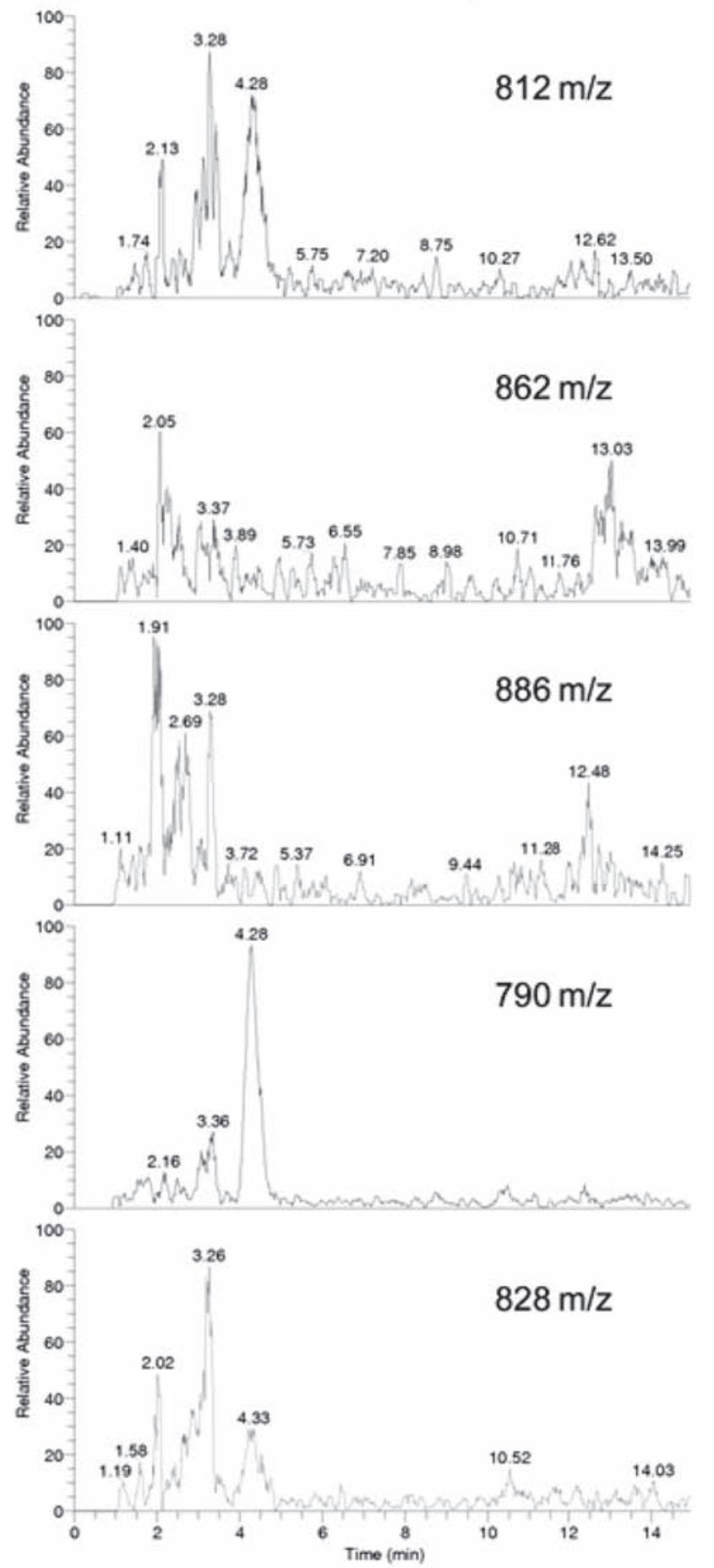

B Native SR Unoxidized

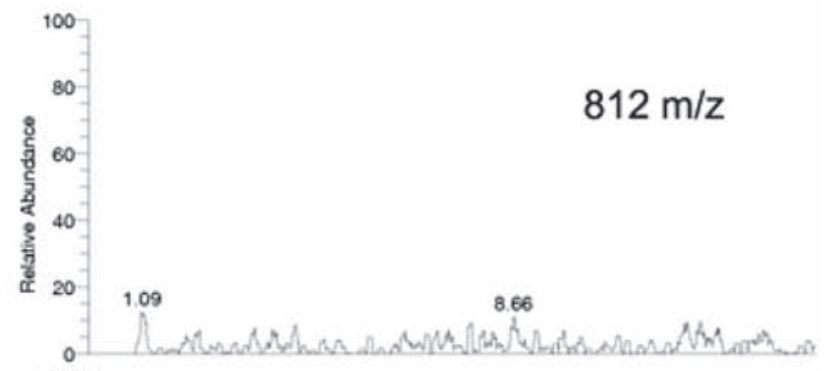

$862 \mathrm{~m} / \mathrm{z}$

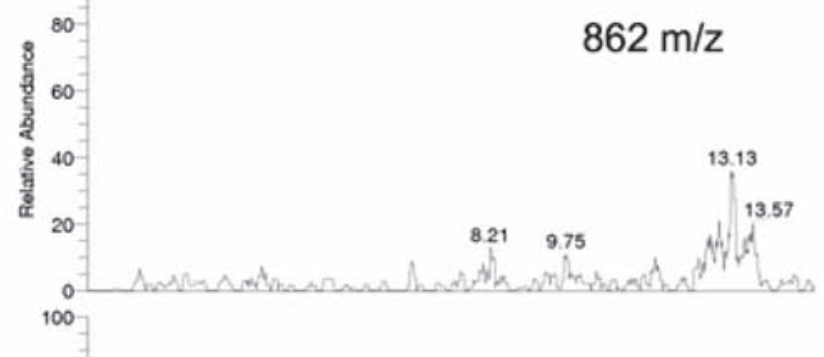

$886 \mathrm{~m} / \mathrm{z}$

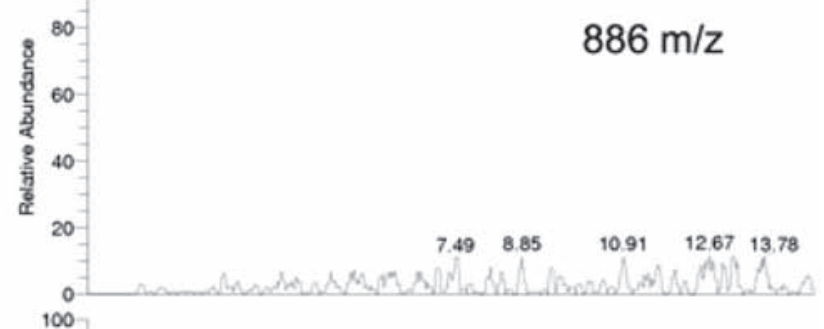

$790 \mathrm{~m} / \mathrm{z}$

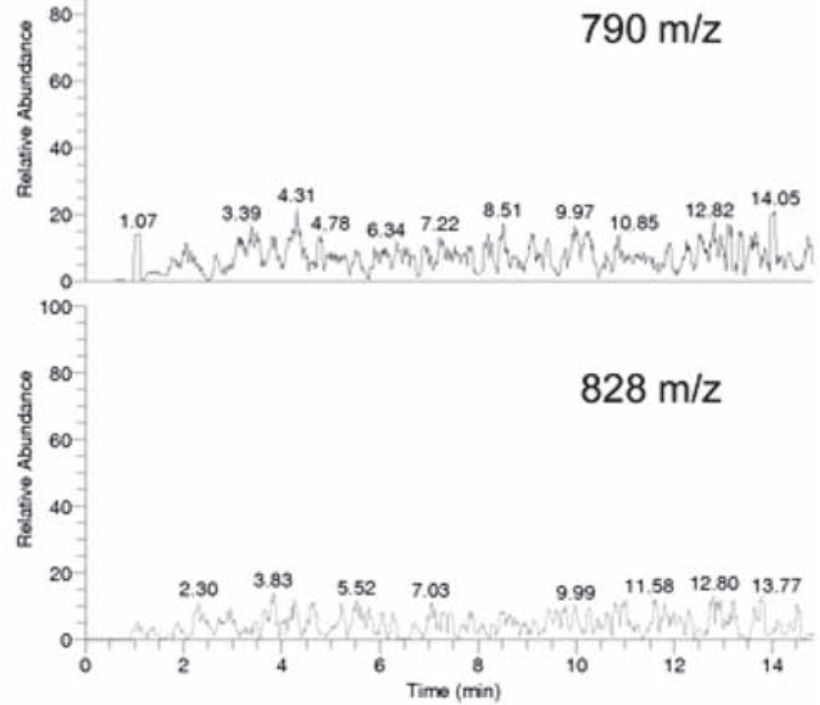

Figure 5. Reconstructed ion chromatograms of oxidised phosphatidylcholines in SR vesicles. Spectra were recorded on a ThermoFinnigan LCQ. A. Data from SR ( $1 \mathrm{mg}$ prot./ml) oxidised by $10 \mathrm{mmol} / 1 \mathrm{HOCl}$ for $2 \mathrm{~h}$ at $37^{\circ} \mathrm{C}$. B. Data from native unoxidised SR, as indicated; $812 \mathrm{~m} / \mathrm{z}$ corresponds to the mono-chlorohydrin of POPC; 862 and $886 \mathrm{~m} / \mathrm{z}$ correspond to bischlorohydrins of PLPC and PAPC respectively; $790 \mathrm{~m} / \mathrm{z}$ corresponds to the monoperoxide of PLPC; $828 \mathrm{~m} / \mathrm{z}$ corresponds to the dehydration product of the bisperoxide of PAPC. The oxidized lipids elute early in the spectra (before $6 \mathrm{~min}$ ); the components eluting after $10 \mathrm{~min}$ in the unoxidised samples are unsaturated native lipids that have the same $\mathrm{m} / \mathrm{z}$ as the oxidised lipid. 
A

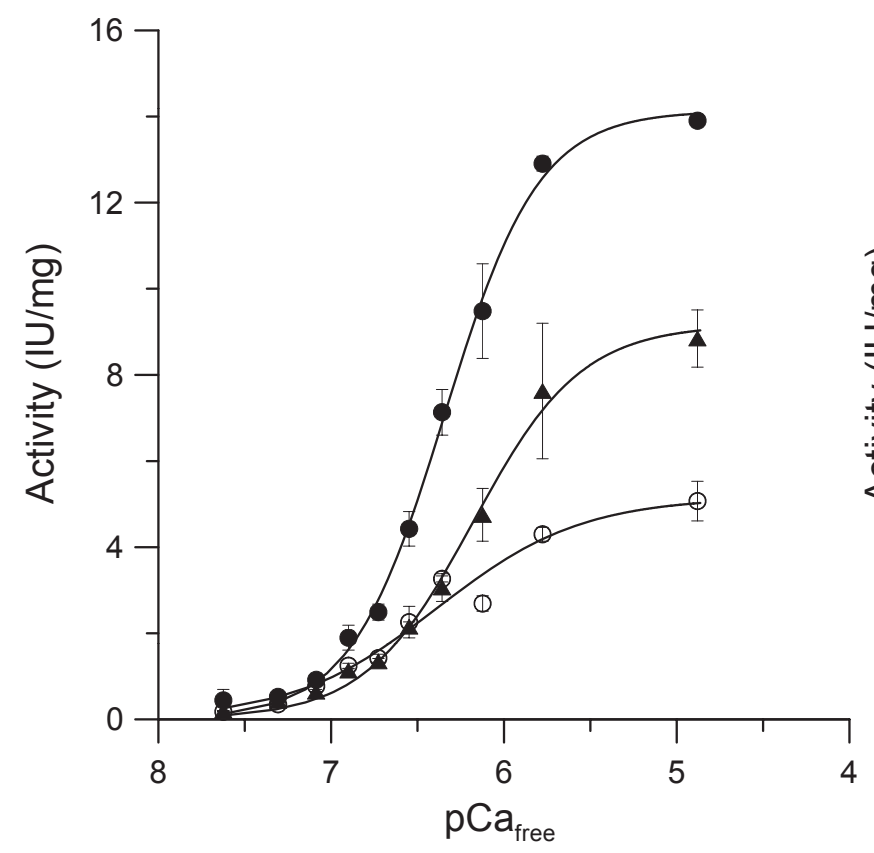

B

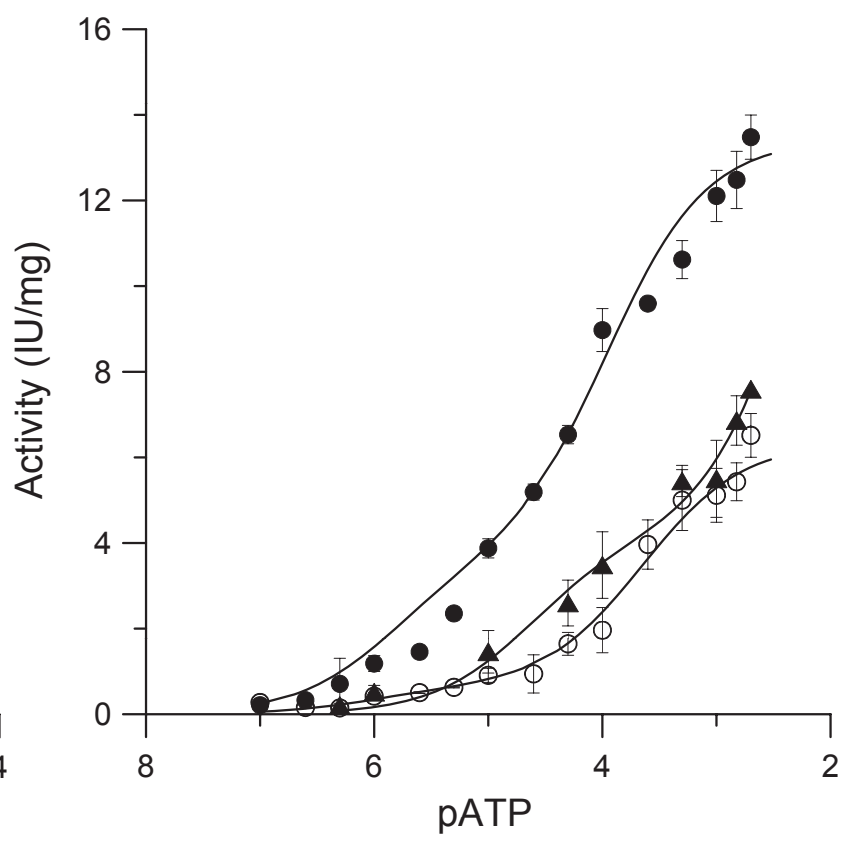

Figure 6. Activity of purified Ca-ATPase as a function of the concentrations of free $\mathrm{Ca}^{2+}(\mathrm{A})$ and ATP (B) in the absence $(\bullet)$ and presence of $\mathrm{HOCl}(\mathrm{O})$ and $\mathrm{HOCl}+\operatorname{trolox}(\boldsymbol{\Delta})$. Ca-ATPase was incubated with $\mathrm{HOCl}(100 \mu \mathrm{mol} / \mathrm{l})$ for $3 \mathrm{~min}$. Trolox $(250 \mu \mathrm{mol} / \mathrm{l})$ was added $2 \mathrm{~min}$ before $\mathrm{HOCl}$ incubation. The kinetic parameters are given in Table 2. Each point is the mean $\pm \mathrm{SEM}$ of at least 3 independent experiments. $\mathrm{pCa}_{\text {free }}=-\log \left[\mathrm{Ca}^{2+}\right.$ free $], \mathrm{pATP}=-\log [\mathrm{ATP}]$, the concentrations of free $\mathrm{Ca}^{2+}$ and ATP was in mol/l ( $\mathrm{p}$ means inverse logarithm).

(C16:0/18:2 at $758 \mathrm{~m} / \mathrm{z}$ and $\mathrm{C} 16: 0 / 20: 4$ at $782 \mathrm{~m} / \mathrm{z}$ ), the PEs tended to contain stearate, such as C18:0/18:2 at $744 \mathrm{~m} / \mathrm{z}$, $\mathrm{C} 18: 0 / 20: 4$ at $768 \mathrm{~m} / \mathrm{z}$ and $\mathrm{C} 18: 0 / 22: 6$ at $792 \mathrm{~m} / \mathrm{z}$. There were also fewer mono-unsaturated fatty acyl chains in PEs compared to PCs.

The presence of oxidised phospholipids in SR membranes was investigated in native unoxidised samples compared to in vitro oxidised samples by $10 \mathrm{mmol} / \mathrm{l} \mathrm{HOCl}$ for $2 \mathrm{~h}$ at $37^{\circ} \mathrm{C}$. The formation of chlorohydrins and hydroperoxides is summarised in Fig. 5. The strongest chlorination product was the monochlorohydrin of palmitoyl-oleoyl PC at $812 \mathrm{~m} / \mathrm{z}$. Bischlorohydrins of palmitoyl-linoleoyl and palmitoylarachidonoyl PC were also evident in the reconstructed ion chromatograms at 862 and $886 \mathrm{~m} / \mathrm{z}$, respectively. $\mathrm{HOCl}$ treatment of SR membranes also resulted in the formation of the monoperoxides of palmitoyl-linoleoyl PC $(790 \mathrm{~m} / \mathrm{z})$ and moreover there was a small amount of peroxides from stearoyl-arachidonoyl PC. Finally, there was evidence for the formation of a bis-peroxide of stearoyl-arachidonoyl PE at $832 \mathrm{~m} / \mathrm{z}$, which is interesting, as reports concerning the observation of $\mathrm{PE}$ oxidation products in biological samples are rather scanty.

Effects of $\mathrm{HOCl}$ and trolox, added before $\mathrm{HOCl}$, on the activity of Ca-ATPase were studied with respect to both free $\mathrm{Ca}^{2+}$ ions and ATP concentrations (Fig. 6). Kinetic param- eters concerning $\mathrm{Ca}^{2+}$ dependence were calculated from the Hill equation (Gould et al. 1986) and the dependence of Ca-ATPase activity on ATP concentration was described by a modified form of the bi-Michaelis-Menten equation according to Kosk-Kosicka et al. (1983) and Michelangeli et al. (1991). These authors suggest that ATP interacts at two sites: a high-affinity (catalytic) site and a low-affinity (regulatory) site.

Kinetic parameters of purified Ca-ATPase activity as a function of free $\mathrm{Ca}^{2+}$ in the absence and presence of $\mathrm{HOCl}$, and in samples oxidised by $\mathrm{HOCl}$ and pretreated by trolox, are summarised in Table $2 \mathrm{~A}$. Concerning the dependence of ATPase activity on $\mathrm{HOCl}(150 \mu \mathrm{mol} / \mathrm{l})$ as a function of free $\mathrm{Ca}^{2+}$ concentration $(0.024-13.5 \mu \mathrm{mol} / \mathrm{l})$, parameters $V_{\text {max }}$ and $h$ decreased significantly, and $K$, characterising affinity of the enzyme to free $\mathrm{Ca}^{2+}$ ions, was within error margins equal to that of control samples. Trolox $(250 \mu \mathrm{mol} / \mathrm{l})$ recovered the decreased Ca-ATPase activity induced by $\mathrm{HOCl}$, as depicted in Fig. 6A. The kinetic parameters concerning increasing free $\mathrm{Ca}^{2+}$ concentration, $K$ and $h$, increased practically to the same values as found without being affected by $\mathrm{HOCl}$, indicating that trolox decreased the affinity of the enzyme for free $\mathrm{Ca}^{2+}$ ions. $V_{\max }$ increased significantly compared with the value observed after $\mathrm{HOCl}$ injury (Table 2A). 
Table 2. Kinetic parameters of purified Ca-ATPase activity as a function of free $\mathrm{Ca}^{2+}($ Part A) and ATP (Part B) concentration in the absence and presence of $\mathrm{HOCl}$ and $\mathrm{HOCl}+$ trolox. Each value is the mean $\pm \mathrm{SD}$ of at least three independent experiments

Part A

Part B

\begin{tabular}{|l|c|c|c|c|c|c|c|c|c|c|}
\hline & \multicolumn{4}{|c|}{} & \multicolumn{2}{c|}{ Catalytic } & \multicolumn{2}{|c|}{ Regulatory } & \\
\cline { 2 - 11 } & $\begin{array}{c}K_{m} \\
(\mu \mathrm{mol} / \mathrm{l})\end{array}$ & $\begin{array}{c}V_{\max } \\
(\mathrm{IU} / \mathrm{mg})\end{array}$ & $h$ & $r^{2}$ & $\begin{array}{c}K_{m} \\
(\mu \mathrm{mol} / \mathrm{l})\end{array}$ & $\begin{array}{c}V_{\max } \\
(\mathrm{IU} / \mathrm{mg})\end{array}$ & $\begin{array}{c}K_{m} \\
(\mathrm{mmol} / \mathrm{l})\end{array}$ & $\begin{array}{c}V_{\max } \\
(\mathrm{IU} / \mathrm{mg})\end{array}$ & $r^{2}$ \\
\hline Control & $0.46(1)$ & $14.13(1)$ & $1.59(1)$ & 0.998 & $1.4(1)$ & $3.57(1)$ & $0.11(1)$ & $9.87(1)$ & 0.985 \\
\hline $\mathrm{HOCl}(150 \mu \mathrm{mol} / \mathrm{l})$ & $0.41(0.9)$ & $5.16(0.4)$ & $1.03(0.6)$ & 0.963 & $1.0(0.7)$ & $0.64(0.2)$ & $0.23(2.1)$ & $5.71(0.6)$ & 0.970 \\
\hline $\mathrm{HOCl}+\operatorname{trolox}(250 \mu \mathrm{mol} / \mathrm{l})$ & $0.67(1.5)$ & $9.16(0.6)$ & $1.39(0.9)$ & 0.994 & $23.6(17)$ & $4.11(1.1)$ & $7.50(68)$ & $16.71(1.7)$ & 0.984 \\
\hline
\end{tabular}

$V_{\text {max }}$, the maximal reaction rate; $K_{m}$, the Michaelis constant; $h$, the Hill coefficient; $r^{2}$, the correlation coefficient. The numbers in brackets are in relative units, where control samples were set as 1 .

Kinetic parameters of purified Ca-ATPase activity as a function of ATP concentration in the absence and presence of $\mathrm{HOCl}$, and in samples oxidised by $\mathrm{HOCl}$ and pretreated by trolox are summarised in Table 2B. Similarly, the affinity of Ca-ATPase to ATP (0.1-2 mmol/l) was not altered after incubation with $\mathrm{HOCl}$ however, the $V_{\text {max }}$ of the catalytical binding site for ATP decreased significantly. Kinetic parameters of the regulatory binding site were within error margins equal to that of control samples. With increasing ATP concentrations, trolox decreased the affinity of Ca-ATPase to ATP (by increasing $K_{m}$ ), with respect to catalytic as well as to regulatory binding sites. In addition, trolox significantly increased $V_{\text {max }}$ of both catalytic and regulatory binding sites.

\section{Discussion}

ER/SR appears to be one of the most important signal transducting organelles within the cell, activating a multitude of cell functions by releasing $\mathrm{Ca}^{2+}$ and shutting them down by reuptake via the SERCA transport. Reactive oxygen and nitrogen species may induce deranged ER/SR $\mathrm{Ca}^{2+}$ signalling, but they have also physiological benefits.

$\mathrm{HOCl}$ generated during inflammation is a strong oxidant and the membrane enzyme SERCA is extremely sensitive to oxidative stress. It is responsible for maintenance of calcium homeostasis and plays an important role in cell signalling. Therefore we focussed our study on mechanisms of $\mathrm{HOCl}$ induced injury of SERCA and on analysing preventive effects of trolox.

In our recent publication, the concentration of $\mathrm{HOCl}$ which caused 50\% decrease in SR Ca-ATPase activity from rabbit skeletal muscle was determined as $100 \mu \mathrm{mol} / \mathrm{l}$ (Strosova et al. 2005a). Incubation with trolox (50-500 $\mu \mathrm{mol} / \mathrm{l})$ was without any effect on Ca-ATPase activity. When SR vesicles were preincubated with trolox before oxidative injury by $\mathrm{HOCl}$, a concentration-dependent preventive effect of trolox was observed, with a maximum at $250 \mu \mathrm{mol} / \mathrm{l}$ and $\mathrm{IC}_{50}$ at $141.2 \mu \mathrm{mol} / \mathrm{l}\left(r^{2}=0.966\right)$.
According to the dependence of pure Ca-ATPase on increasing $\mathrm{HOCl}$ concentration, 50\% decrease in SR Ca-ATPase activity was determined as $150 \mu \mathrm{mol} / \mathrm{l}$. Such a concentration of $\mathrm{HOCl}$ may be present in tissues under certain conditions of inflammation (Schaur et al. 1998; Winterbourn and Kettle 2000; Spalteholz et al. 2006). One of the fastest known reactions of $\mathrm{HOCl}$ with cell components are reactions with thiols (Vissers and Winterbourn 1995; Winterbourn and Brennan 1997; Schaur et al. 1998; Ying et al. 2007, 2008).

In SR, more than $90 \%$ of the free protein thiols are located on SERCA (Majima et al. 1995; Viner et al. 1999). Cystein thiol groups are particularly sensitive to oxidation by reactive oxygen or nitrogen species (Squier and Bigelow 2000; Cohen and Adachi 2006; Ying et al. 2007, 2008). Modification of reactive cysteine thiols resulting in generation of disulfides not only affects protein structure but can alter the function of proteins by modulation of enzymatic activity (Cohen and Adachi 2006).

Oxidation of cysteines can modulate calcium homeostasis (Cohen and Adachi 2006; Dremina et al. 2007; Ying et al. 2007, 2008). Ion channels and pumps belong to proteins regulated by cysteine thiol groups (Adachi et al. 2005; Cohen and Adachi 2006). The redox state of specific cystein residues of SERCA is important for enzymatic function so that modification of different SERCA cystein residues may result in both inhibition and activation of the enzyme (Viner et al. 1999; Adachi et al. 2004; Li and Camacho 2004). The regulation of intracellular calcium by SERCA has an impact on vascular relaxation, cardiac and skeletal muscle relaxation, as well as cell on growth and diferentiation (Babu and Periasamy 2005; Vangheluwe et al. 2005; Cohen and Adachi 2006). Reactive cysteine sites are most involved in reversible S-glutathiolation, but due to their high reactivity, they are also most susceptible to irreversible oxidation by oxidants. The highly reactive peroxinitrite as well as the less reactive $\mathrm{H}_{2} \mathrm{O}_{2}$ and $\mathrm{HOCl}$ participate in both physiological regulation (at low levels) and exert also pathologic effects (at chronically higher levels) (Cohen and Adachi 2006). 
In the present study the concentration of $6.6 \mu \mathrm{mol} / \mathrm{HOCl}$, reducing the level of SH groups to $50 \%$, did not affect the enzyme activity at all. It means that low concentrations of $\mathrm{HOCl}$ were not critical for impairment of SR Ca-ATPase activity in our experiments. However, the ability of low $\mathrm{HOCl}$ concentrations $(10-20 \mu \mathrm{mol} / \mathrm{l})$ to oxidise plasma membrane thiols was reported by Schaur et al. (1998). On the other hand, when SR was oxidised by $\mathrm{HOCl}$, the $\mathrm{SH}$ reducing agents glutathione and dithiothreitol protected at least partially Ca-ATPase activity in our experiments (Strosova et al. 2005a). Experiments of Favero et al. (1998), when SR was oxidised by $\mathrm{HOCl}$, indicated that SH groups might be involved in $\mathrm{HOCl}$-induced injury. The molecule of Ca-ATPase from SR of rabbit skeletal muscle has been shown to possess $26 \mathrm{SH}$ groups containing cysteine residues, 6 of which are in the disulfide conformation, leaving 20 free SH groups (MacLennan et al. 1985; Vangheluwe et al. 2005), while only 1-2 of them (located in the transmembrane region of the enzyme molecule) are essential for enzyme catalysis (Scherer and Deamer 1986; Kawakita and Yamashita 1987). This fact may contribute to the high variability of correlation between the SH content and enzyme activity in different preparations. Thiols function not only in normal cell signalling via S-nitrosation, S-glutathiolation or S-sulfenation but also may be irreversibly oxidised (generating cysteine sulfonic acids) by aging and diseases, and thus interfering with protein function (Ying et al. 2007). An example may be SERCA reversibly regulated through NO-dependent Sglutathiolation of specific cysteine residues of SERCA from smooth muscle cells (Ying et al. 2007; Tong et al. 2008). The irreversible oxidation of cysteine residues could impair NO-dependent muscle relaxation (Dremina et al. 2007). In our in vitro experiments, where SERCA from rabbit muscles was oxidized by $\mathrm{HOCl}$, we found that SERCA activity was only partially recovered by glutathione or 1,4-dithiotreitol (Strosova et al. 2005b), which may suggest generation of irreversible cysteine oxidation products or involvement of other types of oxidation.

Protein peptide bond fragmentation in the membrane was observed only at high $\mathrm{HOCl}$ concentrations (Vissers et al. 1994). According to SDS-PAGE of HOCl-oxidised $\mathrm{SR}$, a new band was observed at $75 \mathrm{kDa}$, probably generated by increasing fragmentation due to protein carbonyl formation. This appears to be supported by immunoblotting, using antibodies against carbonyls derivatized with dinitrophenyl hydrazine, with the band appearing also around $75 \mathrm{kDa}$. The density of this band was more intense at the higher concentration of $\mathrm{HOCl}(200 \mu \mathrm{mol} / \mathrm{l})$ compared with the lower one $(100 \mu \mathrm{mol} / \mathrm{l})$, and increased over time. Favero et al. (1998) also reported structural damage in $\mathrm{HOCl}$-induced injury to $\mathrm{Ca}$-ATPase, as $\mathrm{HOCl}$ inhibited the binding of the fluorescent probe FITC to ATPase. In our experiments, $\mathrm{HOCl}$ concentration-dependently decreased fluorescence of FITC bound to the nucleotide binding site of Ca-ATPase.

The SR Ca-ATPase contains 13 Trp residues, 11 of them located in the transmembrane part of the protein and two in the cytoplasmic domain. Alteration in Trp fluorescence may be a marker of conformational changes and functional characterization of SERCA (Restall et al. 1986; Boschek et al. 2008; Montigny et al. 2008). Schoneich and Sharov (2006) identified covalent cross-linkings of Trp only on a certain peptide when subjected to hypochlorous acid. The formation of such cross-links induces a kink within the polypeptide backbone and results in a more rigid backbone structure, potentially causing inactivation of target proteins (Fu et al. 2004). We found no changes in the ratio of polar/nonpolar Trp fluorescence intensities when comparing control and $\mathrm{HOCl}$-treated samples. These results indicate that $\mathrm{HOCl}-$ induced decrease in ATPase activity was not associated with conformational changes of the transmembrane part of SERCA. Contrary to other oxidants, $\mathrm{H}_{2} \mathrm{O}_{2}$ was reported to quench Trp fluorescence in plasma membrane Ca-ATPase, an index of conformational changes, with a rate similar to that observed for enzyme inactivation (Zaidi et al. 2003).

However, in our experiments, the decrease in SERCA activity in $\mathrm{SR}$ oxidised by increasing concentrations of $\mathrm{HOCl}$ may have been associated with FITC fluorescence decrease, supporting the notion of conformational changes in other regions of SERCA. Reactions of $\mathrm{HOCl}$ and chloramines with biological material include oxidations and chlorinations. Lysine residues appear to be a major site of reaction of $\mathrm{HOCl}$ with many proteins (Zavodnik et al. 2001). This process yields chloramine species, which subsequently decompose to give nitrogen-centred protein radicals. These radicals are key species in $\mathrm{HOCl}$-induced protein backbone fragmentation and dimerisation. FITC binding is localised to a specific lysine residue $\left(\mathrm{Lys}^{515}\right)$ located in the adenine nucleotide binding site of Ca-ATPase (Hidalgo et al. 1982; Starling et al. 1996; Schertzer et al. 2003; Montigny et al. 2007; Winters et al. 2008). Reaction of the Ca-ATPase with FITC leads to inhibition of ATPase activity as the result of selective modification of the nucleotide binding site (Froud and Lee 1986).

The transmembrane domain of Ca-ATPase of skeletal muscle SR makes contact with about 30 lipid molecules in the membrane (East et al. 1985; Dalton et al. 1998). The major lipids of the SR membrane are PCs, PEs and phosphatidylinositols (Krainev et al. 1995; Dalton et al. 1998). The activity of ATPase is dependent on the chemical structure and physical phase of its surrounding phospholipids (Dalton et al. 1998; Lee 1998; Ahuja et al. 1999; Karlovska et al. 2006, 2007). For example, high ratios of $\omega-6$ to $\omega-3$ polyunsaturated fatty acids increase the activity of SERCA in the SR of the heart (Ruf and Arnold 2008). Phospholipids containing docosahexaenoic acid 22:6( $\omega-3)$ were proposed to be required 
as conformational cofactors for the functional assembly of membrane proteins, such as ion pumps, including SR Ca-ATPase (Infante et al. 2001). The acidic phospholipids stimulated the Ca-ATPase activity in the following order of efficiency: phosphatidylinositol 4-monophosphate > phosphatidylserine $>$ PC congruent with $(\cong)$ PE congruent with

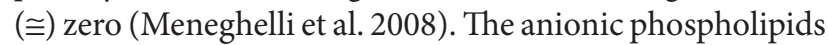
could induce a conformational change in ATPase, resulting in modulation of the enzyme activity (Dalton et al. 1998; Lee 1998; Carney et al. 2007). Lipid oxidation may induce structural changes in the lipid bilayer, which could indirectly inhibit the activity of the pump (Filipek et al. 1993; Karlovska et al. 2007). In our experiments, the concentration of 150 $\mu \mathrm{mol} / \mathrm{l} \mathrm{HOCl}$, reducing the SERCA activity to $50 \%$, did not affect PCs and PEs composition. This low concentration of $\mathrm{HOCl}$ was not critical for oxidation of SR lipids. Higher concentrations of $\mathrm{HOCl}(10 \mathrm{mmol} / \mathrm{l})$ induced oxidation of PCs and PEs, indicating that SERCA activity was indirectly not influenced through the lipid environment of SERCA protein.

Purified Ca-ATPase activity was analysed individually with respect to both substrates, free $\mathrm{Ca}^{2+}$ and ATP. The typical bell-shaped dependence of ATPase activity on free $\mathrm{Ca}^{2+}$ concentration with a maximum at $1.7 \mu \mathrm{mol} / \mathrm{l}$ free $\mathrm{Ca}^{2+}$ as determined in our study was comparable with the results of Brown et al. (1994). Also the parameter $K$ (the substrate concentration of half the maximal reaction rate) of the stimulatory phase and the $\mathrm{IC}_{50}$ of the inhibitory phase were comparable with the results of Brown et al. (1994). The dependence of SR ATPase activity on ATP concentration was very well described in our experiments by the bi-MichaelisMenten equation (Kosk-Kosicka et al. 1983), assuming that ATP interacts at two sites: a high affinity (catalytic) and a low affinity (regulatory) site (Kosk-Kosicka et al. 1983; Gould et al. 1986; Michelangeli et al. 1991). Using the bi-MichaelisMenten equation, we found high affinity (catalytic) kinetic parameters $K_{m}=1.4 \mu \mathrm{mol} / 1, V_{\max }=3.6 \mathrm{IU} / \mathrm{mg}$ and low affinity (regulatory) parameters $K_{m}=0.1 \mathrm{mmol} / \mathrm{l}, V_{\text {max }}=$ $9.9 \mathrm{IU} / \mathrm{mg}$ and $r^{2}=0.985$. These kinetic parameters were comparable with those found by Bilmen et al. (2002).

Only maximal reaction rates $V_{\text {max }}$ (concerning $\mathrm{Ca}^{2+}$ as well as ATP dependence) of Ca-ATPase activity were decreased. The affinity of the enzyme either to free $\mathrm{Ca}^{2+}$ ions or to ATP was not influenced by $\mathrm{HOCl}$. This observation is in correlation with results of Kato et al. (1998) on cardiac sarcolemmal $\mathrm{Na}^{+}, \mathrm{K}^{+}$-ATPase activity. In the presence of different concentrations of ATP, a decrease was found in the $V_{\max }$ value, without a change in affinity for ATP on treatment of sarcolemmal membranes with $100 \mu \mathrm{mol} / 1 \mathrm{HOCl}$. The $V_{\text {max }}$ value of $\mathrm{Na}^{+}, \mathrm{K}^{+}$-ATPase, when determined in the presence of increasing concentrations of $\mathrm{Na}^{+}$, was also decreased.

In summary, this study found that $\mathrm{HOCl}$ caused a rapid loss of Ca-ATPase activity related to a decrease in maximal reaction rate $V_{\max }$ (corresponding to decrease in maximum catalytic activity) rather than to changes in substrate binding affinities. The loss of activity could not be explained solely by loss of thiol ( $\mathrm{SH}$ ) groups as these were depleted at much lower $\mathrm{HOCl}$ concentrations than those required to decrease enzymatic activity. Yet there was evidence from FITC fluorescence experiments that oxidation of Lys ${ }^{515}$ in the catalytic site might contribute to this effect. At least over the short timescale of enzyme inactivation studied, Trp oxidation and conformational change in the transmembrane region did not appear to be involved in the process. Although at lower concentrations we observed fragmentation of SR protein and after longer $\mathrm{HOCl}$ treatments, or higher concentrations also protein carbonyl formation (at extremely high $\mathrm{HOCl}$ concentrations also phospholipids oxidation), these processes did not contribute causatively to the loss of Ca-ATPase activity but rather reflected continuing and more extensive oxidative damage. This may, nevertheless, be involved in a different way in SR and cell dysfunction.

A protective effect of $\alpha$-tocopherol on Ca-ATPase activity was reported in several animal models, like thermal ischaemia of rat kidney (Golod 1997), in hypercholesterolaemic rabbits (Kuzmina et al. 1986), after catecholamine induced changes in cardiac sarcolemmal Ca ${ }^{2+}$ transport (Tappia et al. 2001), streptozotocin-induced diabetic rat kidney (Pekiner et al. 2003), or acute inflammation of rat pancreas, liver and kidney tissues (Qiu et al. 2004).

Trolox, a water soluble derivative of $a$-tocopherol, inhibited peroxynitrite mediated oxidative stress and apoptosis in rat thymocytes (Salgo and Pryor 1996) and was able to scavenge peroxinitrite (Gutierrez-Martin et al. 2004). Trolox was more effective than ascorbic acid in preventing the degradation of Trp and Tyr residues of proteins (Yettella and Min 2008). Trolox inhibited the lipid peroxidation of unilamellar liposomes and carbonyl production in plasma proteins and BSA induced by $\mathrm{Fe}^{2+} / \mathrm{H}_{2} \mathrm{O}_{2}$ (Sivonova et al. 2006). Troloxderived phenoxyl radicals were determined in the mixture of $\mathrm{BSA}, \mathrm{HOCl}$ and trolox, but were not observed when $\mathrm{HOCl}$ was incubated with trolox alone (Hawkins and Davies 1998). The detection of trolox-derived EPR signals was ascribed to oxidation of trolox by radicals formed on HOCl-treated BSA as a result of decomposition of chloramine species, which are early products of $\mathrm{HOCl}$ oxidation.

A significant concentration-dependent protective effect of trolox on SR Ca-ATPase activity from rabbit muscle oxidised by $\mathrm{HOCl}$ was reported in our recent publication (Strosova et al. 2005a). Maximum of the protective effect was observed at trolox concentration of $250 \mu \mathrm{mol} / 1$. Under the same conditions of $\mathrm{HOCl}$ oxidation, no protective effects of trolox concerning protein carbonyls or $\mathrm{SH}$ groups of SR were observed (Strosova et al. 2005a) and no scavenging effect of $\mathrm{HOCl}$ by trolox was found (Sivonova et al. 2006). 
Trolox changed the kinetic parameters with respect to $\mathrm{Ca}^{2+}$ as well as to ATP. Using the fluorescent label FITC, specific for nucleotide binding sites, we found that trolox was able to induce conformational changes in SERCA. On the basis of these results we suggest that protective effects of trolox originate in its ability to alter structural properties of $\mathrm{Ca}$ ATPase.

Acnowledgements. This study was supported by VEGA 2/5012/27, 2/0001/08, 2/0083/09, APVV-51-017905 and by COST action B35.

\section{References}

Adachi T., Weibrod R. M., Pimentel D. R., Ying J., Sharov V. S., Schoneich C., Cohen R. A. (2004): S-glutathiolation by peroxinitrite activates SERCA during arterial relaxation by nitric oxide. Nat. Med. 10, 1200-1207; doi:10.1038/ nm1119 PMid:15489859

Adachi T., Schoneich C., Cohen R. A. (2005): S-glutathiolation in redox-sensitive signalling Drug. Discov. Today. 2, 39-46; doi:10.1016/j.ddmec.2005.05.022

Ahuja R. P., Borchman D., Dean W. L., Paterson C. A., Zeng J., Zhang Z., Ferguson-Yankey S., Yappert M. C. (1999): Effect of oxidation on Ca2+-ATPase activity and membrane lipids in lens epithelial microsomes. Free Radic. Biol. Med. 27, 177-185; doi:10.1016/S0891-5849(99)00068-4 PMid:10443934

Babu G. J., Periasamy M. (2005): Transgenic mouse models for cardiac dysfunction by a specific gene manipulation. Methods Mol. Med. 112, 365-377

Bilmen J. G., Wootton L. L., Michelangeli F. (2002): The mechanism of inhibition of the sarco/endoplasmic reticulum $\mathrm{Ca} 2+$ ATPase by paxilline. Arch. Biochem. Biophys. 406, 55-64; doi:10.1016/S0003-9861(02)00240-0 PMid:12234490

Boschek C. B., Sun H., Bigelow D. J., Squier T. C. (2008): Different conformational switches underlie the calmodulin-dependent modulation of calcium pumps and channels. Biochemistry 47, 1640-1651; doi:10.1021/bi701987n PMid:18201104

Brown G. R., Benyon S. L., Kirk C. J., Wictome M., East J. M., Lee A. G., Michelangeli F. (1994): Characterisation of a novel Ca2+ pump inhibitor (bis-phenol) and its effects on intracellular Ca2+ mobilization. Biochim. Biophys. Acta 1195, 252-258; doi:10.1016/0005-2736(94)90264-X

Buss H., Chan T. P., Sluis K. B., Domigan N. M., Winterbourn C. C. (1997): Protein carbonyl measurement by a sensitive ELISA method. Free Radic. Biol. Med. 23, 361-366 (Erratum in: Free Radic. Biol. Med., 1998, 24, 1352); doi:10.1016/S0891-5849(97)00104-4 PMid:9214571

Castilho R. F., Carvalho P. C., Vercesi A. E., Ferreira S. T. (1996): Oxidative damage to sarcoplasmic reticulun Ca2+-pump induced by $\mathrm{Fe} 2+/ \mathrm{H} 2 \mathrm{O} 2 /$ ascorbate is not mediated by lipid peroxidation or thiol oxidation and leads to protein fragmentation. Mol. Cell. Biochem. 159, 105-114; doi:10.1007/BF00420912 PMid:8858560
Carney J., East J. M., Lee A. G. (2007): Penetration of lipid chains into transmembrane surfaces of membrane proteins: studies with MscL. Biophys. J. 92, 3556-3563; doi:10.1529/ biophys.106.102210 PMid:17307828 PMCid:1853141

Carr A. C., Winterbourn C. C. (1997): Oxidation of neutrophil glutathione and protein thiols by myeloperoxidase-derived hypochlorous acid. Biochem. J. 327, 275-281

Cohen R. A., Adachi T. (2006): Nitric-oxide-induced vasodilatation: regulation by physiologic S-glutathiolation and pathologic oxidation of the sarcoplasmic endoplasmic reticulum calcium ATPase. Trends Cardiovasc. Med. 16, 109-114; doi:10.1016/j.tcm.2006.02.001 PMid:16713532

Dalton K. A., East J. M., Mall S., Oliver S., Starling A. P., Lee A. G. (1998): Interaction of phosphatidic acid and phosphatidylserine with the Ca2+-ATPase of sarcoplasmic reticulum and the mechanism of inhibition. Biochem. J. 329, 637-646

Dremina E. S., Sharov V. S., Davies M. J., Schöneich C. (2007): Oxidation and inactivation of SERCA by selective reaction of cysteine residues with amino acid peroxides. Chem. Res. Toxicol. 20, 1462-1469; doi:10.1021/tx700108w PMid:17892267

East J. M., Melville D., Lee A. G. (1985): Exchange rates and numbers of annular lipids for the calcium and magnesium ion dependent adenosinetriphosphatase. Biochemistry 24, 2615-2623; doi:10.1021/bi00332a005 PMid:2992571

Favero T. G., Colter D., Hooper P. F., Abramson J. J. (1998): Hypochlorous acid inhibits Ca2+-ATPase from skeletal muscle sarcoplasmic reticulum. J. Appl. Physiol. 84, $425-430$

Filípek J., Gelienová K., Kovács P., Balgavý P. (1993): Effect of lipid autoperoxidation on the activity of the sarcoplasmic reticulum (Ca2+-Mg2+)ATPase reconstituted into egg yolk phosphatidylcholine bilayers. Gen. Physiol. Biophys. 12, 55-68

Froud R. J., Lee A. G. (1986): Conformational transitions in the $\mathrm{Ca} 2++\mathrm{Mg} 2+$-activated ATPase and the binding of $\mathrm{Ca} 2+$ ions. Biochem. J. 237, 197-206

Fu X., Kao J. L., Bergt C., Kassim S. Y., Huq N. P., d'Avignon A., Parks W. C., Mecham R. P., Heinecke J. W. (2004): Oxidative cross-linking of tryptophan to glycine restrains matrix metalloproteinase activity: specific structural motifs control protein oxidation. J. Biol. Chem. 279, 6209-6212; doi:10.1074/jbc.C300506200 PMid:14670964

Golod E. A. (1997): The membrane phospholipid peroxidation and Ca-dependent ATPase activity of the microsomal fractions isolated from rat renal tissue in thermal ischemia with and without alpha-tocopherol protection. Urol. Nefrol. (Mosk.) 5, 5-9 (in Russian)

Gould G. W., East J. M., Froud R. J., McWhirter J. M., Stefanova H. I., Lee A. G. (1986): A kinetic model for the Ca2+-Mg2+activated ATPase of sarcoplasmic reticulum. Biochem. J. 237, 217-227

Gutierrez-Martin Y., Martin-Romero F. J., Iñesta-Vaquera F. A., Gutierrez-Merino C., Henao F. (2004): Modulation of sarcoplasmic reticulum Ca2+-ATPase by chronic and acute exposure to peroxynitrite. Eur. J. Biochem. 271, 2647-2657; doi:10.1111/j.1432-1033.2004.04193.x PMid:15206930 
Hawkins C. L., Davies M. J. (1998): Hypochlorite-induced damage to proteins: formation of nitrogen-centred radicals from lysine residues and their role in protein fragmentation. Biochem. J. 332, 617-625

Hidalgo C., Petrucci D. A., Vergara C. (1982): Uncoupling of Ca2+ transport in sarcoplasmic reticulum as a result of labeling lipid amino groups and inhibition of $\mathrm{Ca} 2+$-ATPase activity by modification of lysine residues of the Ca2+-ATPase polypeptide. J. Biol. Chem. 257, 208-216

Infante J. P., Kirwan R. C., Brenna J. T. (2001): High levels of docosahexaenoic acid (22:6(n-3))-containing phospholipids in high-frequency contraction muscles of hummingbirds and rattlesnakes. Comp. Biochem. Physiol. B., Biochem. Mol. Biol. 130, 291-298; doi:10.1016/S10964959(01)00443-2

Jesaits A. J., Dratz E. A. (1992): The Molecular Basis of Oxidative Damage by Leukocytes. CRC Press, Boca Raton

Karlovska J., Hammel M., Laggner P., Lacko I., Devinsky F., Balgavy P. (2005): Effects of N-alkyl-N,N-dimethylamine-N-oxides on the activity of purified sarcoplasmic reticulum Ca2+-transporting ATPase. Pharmazie 60, 135-137

Karlovska J., Uhrikova D., Kucerka N., Teixeira J., Devinsky F., Lacko I., Balgavy P. (2006): Influence of N-dodecyl-N,Ndimethylamine $\mathrm{N}$-oxide on the activity of sarcoplasmic reticulum $\mathrm{Ca} 2+$-transporting ATPase reconstituted into diacylphosphatidylcholine vesicles: efects of bilayer physical parameters. Biophys. Chem. 119, 69-77; doi:10.1016/ j.bpc.2005.09.007 PMid:16223561

Karlovska J., Devinsky F., Balgavy P. (2007): Effect of amphiphilic surfactant LDAO on the solubilization of DOPC vesicles and on the activity of Ca2+-ATPase reconstituted in DOPC vesicles. Gen. Physiol. Biophys. 26, 290-297

Kato K., Shao Q., Elimban V., Lukas A., Dhalla N. S. (1998): Mechanism of depression in cardiac sarcolemmal Na+K+-ATPase by hypochlorous acid. Am. J. Physiol. 275, 826-831

Kawakita M., Yamashita T. (1987): Reactive sulfhydryl group of sarcoplasmic reticulum ATPase. III. Identification of cysteine residues whose modification with $\mathrm{N}$-etylmaleimid leads to loss of the Ca2+-transporting activity. J. Biochem. 102, 103-109

Kosk-Kosicka D., Kurzmack M., Inesi G. (1983): Kinetic characterization of detergent-solubilized sarcoplasmic reticulum adenobsinetriphosphatase. Biochemistry. 22, 2559-2567; doi:10.1021/bi00279a037 PMid:6222765

Krainev A. G., Ferrington D. A., Williams T. D., Squier T. C., Bigelow D. J. (1995): Adaptive changes in lipid composition of skeletal sarcoplasmic reticulum membranes associated with aging. Biochim. Biophys. Acta 1235, 406-418; doi:10.1016/0005-2736(95)80030-J

Kuzmina I. L., Timofeev A. A., Germanov S. V., Levchenko L. V., Kulish M. A. (1986): Protective effect of $\alpha$-tocopherol on the Ca2+-transport system of the sarcoplasmic reticulum membranes in hypercholesterolemia. Biull. Eksp. Biol. Med. 101, 163165 (in Russian)

Laemmli U. K. (1970): Cleavage of structural proteins during the assembly of the head of bacteriophage T4. Nature 227, 680-685; doi:10.1038/227680a0 PMid:5432063
Lee A. G. (1998): How lipids interact with an intrinsic membrane protein: the case of the calcium pump. Biochim. Biophys. Acta 1376, 381-390

Li Y., Camacho P. (2004): Ca2+-dependent redox modulation of SERCA 2b by ERp57. J. Cell Biol. 164, 35-46; doi:10.1083/ jcb.200307010 PMid:14699087 PMCid:2171954

Majima E., Goto S., Hori H., Shinohara Y., Hong Y. M., Terada H. (1995): Stabilities of the fluorescent SH-reagent eosin-5maleimide and its adducts with sulfhydryl compounds. Biochim. Biophys. Acta 1243, 336-342

MacLennan D. H., Brandl C. J., Korczak B., Green N. M. (1985): Amino-acid seqence of a Ca2+ + Mg2+-dependent ATPase from rabbit muscle sarcoplasmic reticulum, deduced from its complementary DNA sequence. Nature 316, 696-700; doi:10.1038/316696a0 PMid:2993904

Meneghelli S., Fusca T., Luoni L., De Michelis M. I. (2008): Dual mechanism of activation of plant plasma membrane Ca2+-ATPase by acidic phospholipids: evidence for a phospholipid binding site which overlaps the calmodulin-binding site. Mol. Membr. Biol. 25, 539-546; doi:10.1080/09687680802508747 PMid:18988067

Michelangeli F., Grimes E. A., East J. M., Lee A. G. (1991): Effects of phospholipids on the function of $(\mathrm{Ca} 2+-\mathrm{Mg} 2+)$-ATPase. Biochemistry 30, 342-351; doi:10.1021/bi00216a006 PMid:1824818

Montigny C., Picard M., Lenoir G., Gauron C., Toyoshima C., Champeil P. (2007): Inhibitors bound to Ca2+free sarcoplasmic reticulum Ca2+-ATPase lock its transmembrane region but not necessarily its cytosolic region, revealing the flexibility of the loops connecting transmembrane and cytosolic domains. Biochemistry 46, 15162-15174; doi:10.1021/bi701855r PMid: 18052080

Montigny C., Arnou B., Marchal E., Champeil P. (2008): Use of glycerol-containing media to study the intrinsic fluorescence properties of detergent-solubilized native or expressed SERCA1a. Biochemistry 47, 12159-12174; doi:10.1021/ bi8006498 PMid:18947188

Patton C. (2004): Maxchelator. http://www.stanford.edu/ cpatton/ maxc.html

Pekiner B. D., Daş Evcimen N., Ulusu N. N., Bali M., Karasu C. (2003): Effects of vitamin E on microsomal Ca2+-ATPase activity and calcium levels in streptozotocin-induced diabetic rat kidney. Cell Biochem. Funct. 21, 177-182; doi:10.1002/cbf.1016 PMid:12736908

Pullar J. M., Winterbourn C. C., Vissers M. C. (1999): Loss of GSH and thiol enzymes in endothelial cells exposed to sublethal concentrations of hypochlorous acid. Am. J. Physiol., Heart Circ. Physiol. 277, 1505-1512

Qiu Y., Li Y. Y., Li S. G., Song B. G., Zhao G. F. (2004): Effect of Qingyitang on activity of intracellular Ca2+-Mg2+-ATPase in rats with acute pancreatitis. World J. Gastroenterol. 10, 100-104

Restall C. J., Coke M., Phillips E., Chapman D. (1986): Derivative spectroscopy of tryptophan fluorescence used to study conformational transitions in the $(\mathrm{Ca} 2++\mathrm{Mg} 2+)$-adenosine triphosphatase of sarcoplasmic reticulum. Biochim. Biophys. Acta. 874, 305-311 
Robaszkiewicz A., Bartosz G., Soszyński M. (2008a): N-chloroamino acids cause oxidative protein modifications in the erythrocyte membrane. Mech. Ageing Dev. 129, 572-579; doi:10.1016/j.mad.2008.05.007 PMid:18586303

Robaszkiewicz A., Bartosz G., Soszyński M. (2008b): Effect of N-chloroamino acids on the erythrocyte. Free Radic. Res. 42, 30-39; doi:10.1080/10715760701774873 PMid:18324521

Ruf T., Arnold W. (2008): Effects of polyunsaturated fatty acids on hibernation and torpor: a review and hypothesis. Am. J. Physiol., Regul. Integr. Comp. Physiol. 294, 1044-1052; doi:10.1152/ajpregu.00688.2007

Salgo M. G., Pryor W. A. (1996): Trolox inhibits peroxynitrite-mediated oxidative stress and apoptosis in rat thymocytes. Arch. Biochem. Biophys. 333, 482-488; doi:10.1006/ abbi.1996.0418 PMid:8809090

Schaur J. R., Jerlich A., Stelmaszynska T. (1998): Hypochlorous acid as reactive oxygen species. Curr. Top. Biophys. 22, 176-185

Scherer N. M., Deamer D. W. (1986): Oxidative stress impairs the function of sarcoplasmic reticulum by oxidation of sulfhydryl groups in the Ca2+-ATPase. Arch. Biochem. Biophys. 246, 589-601; doi:10.1016/0003-9861(86)90314-0 PMid:2939799

Schertzer J. D., Green H. J., Duhamel T. A., Tupling A. R. (2003): Mechanisms underlying increases in SR Ca2+-ATPase activity after exercise in rat skeletal muscle. Am. J. Physiol., Endocrinol. Metab. 284, 597-610

Schoneich C., Sharov V. S. (2006): Mass spectrometry of protein modifications by reactive oxygen and nitrogen species. Free Radic. Biol. Med. 41, 1507-1520; doi:10.1016/j.free radbiomed.2006.08.013 PMid:17045919

Sivoňová M., Žitňanová I., Horáková L., Štrosová M., Muchová J., Balgavý P., Dobrota D., Duuračková Z. (2006): The combined effect of with ascorbic acid and trolox on the oxidation of lipids Pycnogenol® and proteins. Gen. Physiol. Biophys. 25, 379-396

Soszyński M., Zavodnik I., Zavodnik L., Zylinska L., Bartosz G., Bryszewska M. (2002): Hypochlorous acid inhibits glutathione S-conjugate export from human erythrocytes. Biochim. Biophys. Acta 1564, 479-486; doi:10.1016/ S0005-2736(02)00500-X

Spalteholz H., Panasenko O. M., Arnhold J. (2006): Formation of reactive halide species by myeloperoxidase and eosinophil peroxidase. Arch. Biochem. Biophys. 445, 225-234; doi:10.1016/j.abb.2005.06.025 PMid:16111649

Spickett C. M., Rennie N., Winter H., Zambonin L., Landi L., Jerlich A., Schaur R. J., Pitt A. R. (2001): Detection of phospholipid oxidation in oxidatively stressed cells by reversed-phase HPLC coupled with positive-ionization electrospray corretion of electroscopy MS. Biochem. J. 355, 449-457 (Erratum in: Biochem. J., 2001, 357, 911); doi:10.1042/0264-6021:3550449 PMid:11284733 PMCid:1221757

Squier T. C., Bigelow D. J. (2000): Protein oxidation and age-dependent alterations in calcium homeostasis. Front. Biosci. 5, 504-526; doi:10.2741/Squier PMid:10799358
Starling A. P., East J. M., Lee A. G. (1996): Stimulation of the $\mathrm{Ca} 2+-\mathrm{ATPase}$ of sarcoplasmic reticulum by disulfiram. Biochem. J. 320, 101-105

Strosova M., Skuciova M., Horakova L. (2005a): Oxidative damage to $\mathrm{Ca} 2+-\mathrm{ATPase}$ sarcoplasmic reticulum by $\mathrm{HOCl}$ and protective effect of some antioxidants. Biofactors 24, 111-116; doi:10.1002/biof.5520240113 PMid:16403970

Strosova M., Skuciova M., Horakova L. (2005b): Oxidative modification of sarcoplasmic reticulum Ca2+-ATPase from rabbit skeletal muscle. Biologia 60, 155-158

Tappia P. S., Hata T., Hozaima L., Sandhu M. S., Panagia V., Dhalla N. S. (2001): Role of oxidative stress in catecholamineinduced changes in cardiac sarcolemmal Ca2+ transport. Arch. Biochem. Biophys. 387, 85-92; doi:10.1006/ abbi.2000.2234 PMid:11368187

Tong X., Ying J., Pimentel D. R., Trucillo M., Adachi T., Cohen R. A. (2008): High glucose oxidizes SERCA cysteine674 and prevents inhibition by nitric oxide of smooth muscle cell migration. J. Mol. Cell. Cardiol. 44, 361-369; doi:10.1016/j.yjmcc.2007.10.022 PMid:18164028 PMCid:2394666

Vangheluwe P., Raeymaekers L., Dode L., Wuytack F. (2005): Modulating sarco(endo)plasmic reticulum Ca2+ ATPase 2 (SERCA2) activity: cell biological implications. Cell Calcium 38, 291-302; doi:10.1016/j.ceca.2005.06.033 PMid:16105684

Viner R. I., Williams T. D., Schoneich C. (1999): Peroxynitrite modification of protein thiols: oxidation, nitrosylation, and S-glutathiolation of functionally important cysteine residue(s) in the sarcoplasmic reticulum Ca-ATPase. Biochemistry 38, 12408-12415; doi:10.1021/bi9909445 PMid:10493809

Vissers M. C., Stern A., Kuypers F., van den Berg J., Winterbourn C. C. (1994): Membrane changes associated with lysis of red blood cells by hypochlorous acid. Free Radic. Biol. Med. 16, 703-712; doi:10.1016/0891-5849(94)90185-6 PMid:8070673

Vissers M. C., Winterbourn C. C. (1995): Oxidation of intracellular glutathione after exposure of human red blood cells to hypochlorous acid. Biochem. J. 307, 57-62

Vissers M. C., Pullar J. M., Hampton M. B. (1999): Hypochlorous acid causes caspase activation and apoptosis or growth arrest in human endothelial cells. Biochem. J. 344, 443449; doi:10.1042/0264-6021:3440443 PMid:10567227 PMCid:1220662

Warren G. B., Toon P. A., Birdsall N. J., Lee A. G., Metcalfe J. C. (1974a): Reconstitution of a calcium pump using defined membrane components. Proc. Natl. Acad. Sci. U.S.A. 71, 622-626; doi:10.1073/pnas.71.3.622

Warren G. B., Toon P. A., Birdsall N. J., Lee A. G., Metcalfe J. C. (1974b): Reversible lipid titrations of the activity of pure adenosine triphosphatase-lipid complexes. Biochemistry 13, 5501-5507; doi:10.1021/bi00724a008 PMid:4281664

Winterbourn C. C., Brennan S. O. (1997): Characterization of the oxidation products of the reaction between reduced glutathione and hypochlorous acid. Biochem. J. 326, $87-92$ 
Winterbourn C. C., Kettle A. J. (2000): Biomarkers of myeloperoxidase-derived hypochlorous acid. Free Radic. Biol. Med. 29, 403-409; doi:10.1016/S0891-5849(00)00204-5 PMid:11020661

Winterbourn C. C. (2002): Biological reactivity and biomarkers of the neutrophil oxidant, hypochlorous acid. Toxicology 181-182, 223-227; doi:10.1016/S0300-483X(02)00286-X PMid:12505315

Winters D. L., Autry J. M., Svensson B., Thomas D. D. (2008): Interdomain fluorescence resonance energy transfer in SERCA probed by cyan-fluorescent protein fused to the actuator domain. Biochemistry 47, 4246-4256; doi:10.1021/bi702089j PMid:18338856

Yettella R. R., Min D. B. (2008): Quenching mechanisms and kinetics of trolox and ascorbic acid on the riboflavin-photosensitized oxidation of tryptophan and tyrosine. J. Agric. Food Chem. 56, 10887-10892; doi:10.1021/jf8006739 PMid:18975971

Ying J., Clavreul N., Sethuraman M., Adachi T., Cohen R. A. (2007): Thiol oxidation in signaling and response to stress: detection and quantification of physiological and pathophysiological thiol modifications. Free Radic. Biol. Med. 43, 1099-1108; doi:10.1016/j.freeradbiomed.2007.07.014 PMid:17854705 PMCid:2043132
Ying J., Sharov V., Xu S., Jiang B., Gerrity R., Schöneich C., Cohen R. A. (2008): Cysteine-674 oxidation and degradation of sarcoplasmic reticulum Ca2+ ATPase in diabetic pig aorta. Free Radic. Biol. Med. 45, 756-762; doi:10.1016/ j.freeradbiomed.2008.05.029 PMid:18590812

Zabe M., Feltzer R. E., Malle E., Sattler W., Dean W. L. (1999): Effects of hypochlorite-modified low-density and highdensity lipoproteins on intracellular $\mathrm{Ca} 2+$ and plasma membrane Ca2+-ATPase activity of human platelets. Cell Calcium 26, 281-287; doi:10.1054/ceca.1999.0081 PMid:10668566

Zaidi A., Barron L., Sharov V. S., Schoneich C., Michaelis E. K., Michaelis M. L. (2003): Oxidative inactivation of purified plasma membrane Ca2+-ATPase by hydrogen peroxide and protection by calmodulin. Biochemistry 42, 1200112010; doi:10.1021/bi034565u PMid:14556631

Zavodnik I. B., Lapshina E. A., Zavodnik L. B., Bartosz G., Soszynski M., Bryszewska M. (2001): Hypochlorous acid damages erythrocyte membrane proteins and alters lipid bilayer structure and fluidity. Free Radic. Biol. Med. 30, 363-369; doi:10.1016/S0891-5849(00)00479-2 PMid:11182291

Received: October 1, 2008

Final version accepted: December 15, 2008 